\title{
EPC in the Nordic Countries
}

\author{
EPC Nordic
}

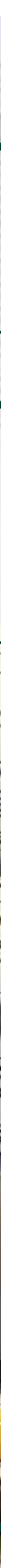







\section{EPC in the Nordic Countries}

EPC Nordic

Liv Randi Lindseth

TemaNord 2015:579 
EPC in the Nordic Countries

EPC Nordic

Liv Randi Lindseth

ISBN 978-92-893-4409-8 (PRINT)

ISBN 978-92-893-4410-4 (PDF)

ISBN 978-92-893-4411-1 (EPUB)

http://dx.doi.org/10.6027/TN2015-579

TemaNord 2015:579

ISSN 0908-6692

(C) Nordic Council of Ministers 2015

Layout: Hanne Lebech

Cover photo: ImageSelect

Print: Rosendahls-Schultz Grafisk

Printed in Denmark

This publication has been published with financial support by the Nordic Council of Ministers. However, the contents of this publication do not necessarily reflect the views, policies or recommendations of the Nordic Council of Ministers.

www.norden.org/nordpub

\section{Nordic co-operation}

Nordic co-operation is one of the world's most extensive forms of regional collaboration, involving Denmark, Finland, Iceland, Norway, Sweden, and the Faroe Islands, Greenland, and Åland.

Nordic co-operation has firm traditions in politics, the economy, and culture. It plays an important role in European and international collaboration, and aims at creating a strong Nordic community in a strong Europe.

Nordic co-operation seeks to safeguard Nordic and regional interests and principles in the global community. Common Nordic values help the region solidify its position as one of the world's most innovative and competitive.

\section{Nordic Council of Ministers}

Ved Stranden 18

DK-1061 Copenhagen K

Phone (+45) 33960200

www.norden.org 


\section{Contents}

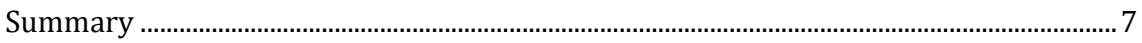

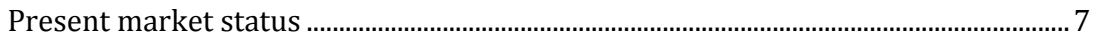

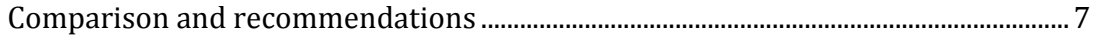

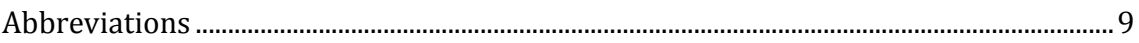

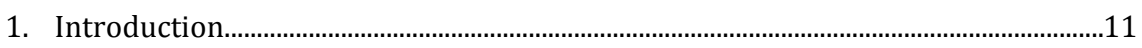

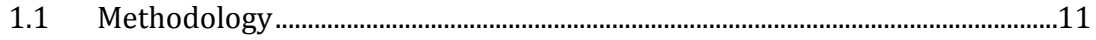

1.2 What is Energy Performance Contracting........................................................12

1.3 Structure................................................................................................................14

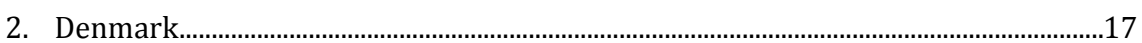

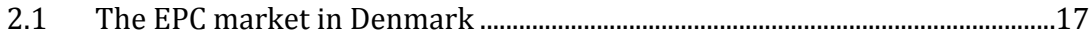

2.2 National characteristics ......................................................................................20

2.3 Governmental strategies to boost the EPC market ..........................................22

2.4 Financial instruments to support EPC ...............................................................23

2.5 Barriers and drivers for increased use of EPC .................................................24

2.6 Future possibilities for EPC in Denmark ..........................................................25

2.7 Central contacts Denmark ............................................................................26

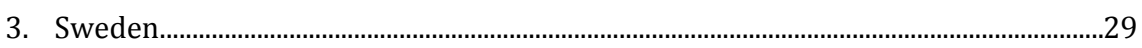

3.1 The EPC market in Sweden ..............................................................................29

3.2 National characteristics ............................................................................................31

3.3 Governmental strategies to boost the EPC market ...........................................34

3.4 Financial instruments to support EPC ……........................................................36

3.5 Barriers and drivers for increased use of EPC ...................................................36

3.6 Future possibilities for EPC in Sweden ................................................................

3.7 Central contacts Sweden ........................................................................................

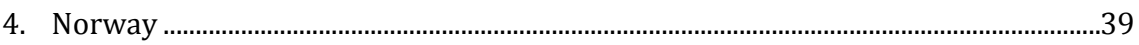

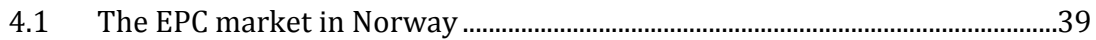

4.2 National characteristics .........................................................................................41

4.3 Governmental strategy to boost the EPC market............................................43

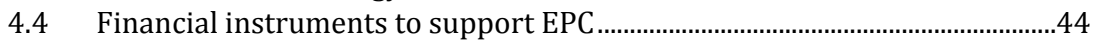

4.5 Barriers and drivers for increased use of EPC ..................................................4

4.6 Future possibilities for EPC in Norway ………....................................................4

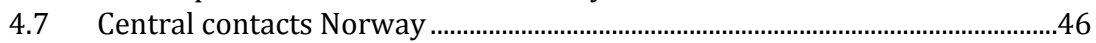

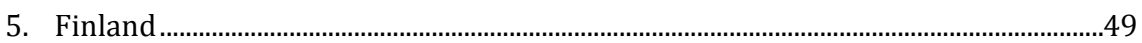

5.1 The EPC market in Finland ..............................................................................49

5.2 National characteristics of EPC - short description of the model..................51

5.3 Governmental strategies to boost the EPC market ...........................................52

5.4 Financial instruments to support EPC ..............................................................53

5.5 Barriers and drivers for increased use of EPC ...............................................53

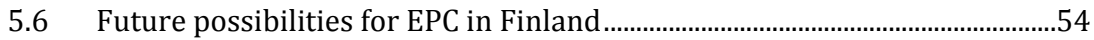

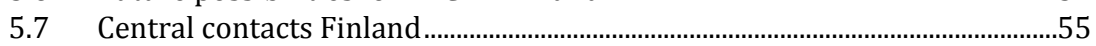




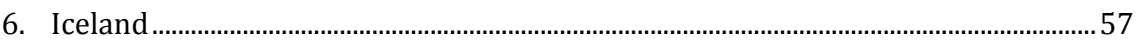

6.1 The EPC market in Iceland ..............................................................................57

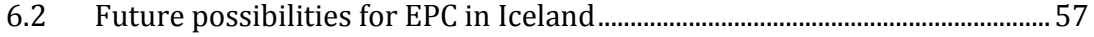

6.3 Governmental strategies........................................................................................59

6.4 Central contacts Iceland ....................................................................................5

7. Comparison and Recommendations................................................................................61

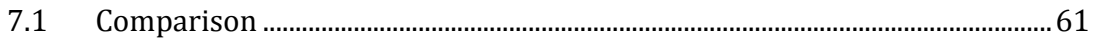

7.2 Overview of the Nordic EPC market - tables .........................................................66

7.3 Preliminary recommendations ………………………………………………...... 70

Sammendrag .........................................................................................................

EPC i de Nordiske landene...............................................................................................75

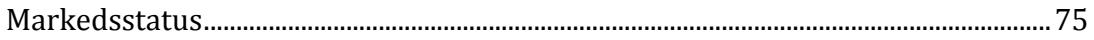

Sammenlikninger og anbefalinger ...................................................................................76

References...................................................................................................................

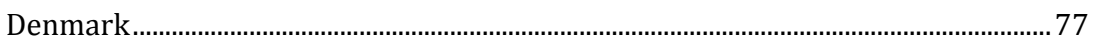

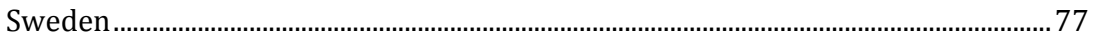

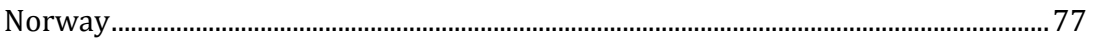

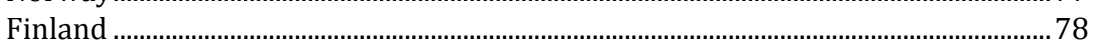

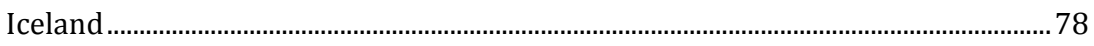




\section{Summary}

The present report aims at describing the EPC markets in the Nordic countries, their special features, traits and differences as well as the success factors and barriers. The aim is to provide recommendations for action for the successful development of the EPC market in Denmark, Sweden, Norway, Finland and Iceland and possible cooperation to promote EPC in and between these countries.

For all the countries, beside Iceland, there have been EPC projects in both public and private sector. We will however focus on public sector for two reasons. First, this sector seems to be more promising in terms of saving potential, customer demand and project volumes, and second, public sector is better monitored by the energy authorities for obvious reasons.

\section{Present market status}

In Denmark and Norway, the EPC market is strong and further growth is expected provided that the current framework is maintained. In the first years of 2000 Sweden was one of the leading countries on EPC and looked upon as a pioneer and good example for the rest of Europe. However, in the last few years, the Swedish EPC market has been week, struggling with issues of knowledge, trust and uncertainties around public procurements. In Finland, the market is slow and small, but experiences more interest in public sector. In both Sweden and Finland, recent positive signs are detected and recent projects can serve as best practise examples and the long needed push in the right direction.

\section{Comparison and recommendations}

A good business culture is crucial as the nature and complexity of EPC projects requires mutual trust in both technical skills and ethical behaviour. All the four countries already have strong, well established business cultures, and hence a common success factor for EPC. 
EPC has a different start up and the development of the EPC market has followed different routes in the four countries. In Denmark the municipalities themselves have been the main driving force, in Norway one EPC facilitator has played an active role and in Sweden the EPC providers have been decisive drivers and in Finland the energy authorities have been in charge for important promotion activities.

In all countries, financial support schemes, success stories and documented results have been important when present.

On the downside the lack of knowledge and trust, the lack of active facilitators and the complexity of the EPC concept and procurement laws have slowed down the progress.

Based on the comparison of what worked and did not work in each country the preliminary recommendations for the promotion and further development of EPC in the Nordic countries are:

- Governmental promotion strategies for information and training for all relevant stakeholders.

- Financial support schemes.

- Development of National Standards for EPC.

- EPC website(s).

- Increased number of EPC facilitators.

Some of the countries have implemented these recommendations to varying extent. A general recommendation would be to take the success factors from each country, and adapt and implement these in the other Nordic countries. 


\section{Abbreviations}

EE

RES

EPC

ESCO

EED

EPC Client

EPC Facilitator
Energy Efficiency.

Renewable Energy Sources.

Energy Performance Contracting.

Energy Service Company (EPC provider).

Energy Efficiency Directive.

The EPC customer and building owner.

Consultant supporting the EPC Client in the preparation of EPC projects.

The expressions above are explained in more detail in chapter 3.2 "What is Energy Performance Contracting". 



\section{Introduction}

\subsection{Methodology}

The contents of this report are based on the following main sources:

- The results of a nation-wide EPC survey among the countries main actors in the autumn of 2013 and in June 2015 (Transparense). ${ }^{1}$

- Input from one or more EPC experts in each Nordic county.

- Recent presentations by Energy Authorities and Lending institutions. $^{2}$

- The market knowledge of the authors, as well as research from local/national literature (publications and studies, legislation documents, official statistics and databases).

For Denmark, Sweden and Norway, the main source for the data used in this document was in country reports on Energy Performance Contracting (EPC) developed by the Transparense project. The report also gives an overview of the development of the EPC market in Finland and Iceland based on feedback from the energy authorities in each of the two countries. In Iceland, there are no known EPC projects so far. We will hence concentrate on providing possible explanations and thoughts about future market potential based on feedback from energy authorities.

This report will also make recommendations for further development and cooperation in and between the different Nordic EPC markets. These recommendations are based on the comparison of the different Nordic EPC markets, as well as on the input from experts in Denmark, Sweden, Norway and Finland and their knowledge of the national market development and relevant literature/research piece.

\footnotetext{
${ }^{1}$ Transparense is an ongoing EU project (2013-2015) with the goal to increase the transparency and trustworthiness of Energy Performance Contracting (EPC) markets throughout Europe.

${ }_{2}^{2}$ Presentations are listed under References.
} 


\subsection{What is Energy Performance Contracting}

Energy Performance Contracting (EPC) is when an energy service company (ESCO) is engaged to improve the energy efficiency of a facility, with guaranteed energy savings paying for the capital investment required to implement improvements. Under a performance contract for energy saving, the ESCO examines a facility, evaluates the level of energy savings that can be achieved, and then offers to implement the project and guarantee those savings over an agreed time period.

A typical EPC project is delivered by an Energy Service Company (ESCO) and consists of the following elements:

- Turnkey Service - The ESCO provides all of the services required to design and implement a comprehensive project at the customer facility, from the initial energy audit through long-term Measurement and Verification (M\&V) of project savings.

- Comprehensive Measures - The ESCO tailors a comprehensive set of measures to fit the needs of a particular facility, include energy efficiency and in addition, can include renewables, distributed generation and water conservation.

- Project financing - The ESCO arranges for project financing, sometimes provided by a third-party financing company in the form of a bank loan.

- Project Savings Guarantee - The ESCO provides a guarantee that the savings produced by the project will be sufficient to cover the cost of project financing for the life of the project.

Energy Performance Contracting allows facility owners and managers to upgrade ageing and inefficient assets while recovering capital required for the upgrade directly from the energy savings guaranteed by the ESCO. The ESCO takes the technical risk and guarantees the savings. The contract period is the pay-back time of the measures. After the end of the specific contract period, the full benefits of the cost savings revert to the facility owner/client. The methodology of EPC differs from traditional contracting, which is invariably price-driven. EPC is results-driven: ensuring quality of performance. 
While there are a vast number of definitions of EPC within Europe, for the purpose of this report we use the definition provided by the Energy Efficiency Directive (EED): ${ }^{3}$

Energy performance contracting means a contractual arrangement between the beneficiary and the provider of an energy efficiency improvement measure, verified and monitored during the whole term of the contract, where investments (work, supply or service) in that measure are paid for in relation to a contractually agreed level of energy efficiency improvement or other agreed energy performance criterion, such as financial savings.

Further, in this report, we define the companies providing EPC as follows:

EPC provider means a natural or legal person who delivers energy services in the form of Energy Performance Contracting (EPC) in a final customer's facility or premises.

Such definition respects the fact that EPC is only one type of energy services, and is in line with the definition of the energy services provider specified in the EED (for its definition see the glossary at the end of the report). In this report we will use the commonly used term "ESCO" as equivalent of the energy service provider.

EPC facilitator means a consultant or consultancy company that supports the EPC Client in the preparation of the EPC project by helping drawing up contracts, recommend technical and commercial targets, formal/technical co-ordination of the tendering process and possible project controlling.

The terms ESCO projects vs EPC project:

The EPC model in Denmark and Finland is usually called the "ESCO model" and an EPC project an "ESCO project". In most European countries, a company can be an ESCO without offering EPC as part of their services. Hence, an ESCO offering EPC are referred to as an EPC provider. For the purpose of this report, we stick to the more common definitions of ESCOs, EPC providers and EPC projects and hence use these terms for Denmark and Finland as well.

${ }^{3}$ Directive 2012/27/EU of the European Parliament and of the Council on energy efficiency, amending Directives 2009/125/EC and 2010/30/EU and repealing Directives 2004/8/EC and 2006/32/EC was approved on 25 October 2012 . 


\subsection{Structure}

We will describe EPC in Denmark, Sweden, Norway, Finland and Iceland based on the following structure:

- The EPC market in the Country:

- Short history.

- Number of projects.

- EPC providers.

- EPC clients.

- EPC facilitators.

- National characteristics:

- National EPC models.

- Support schemes.

- Typical EPC projects; sector, size, savings.

- The most recent projects.

- Governmental strategies to boost the EPC market:

- Legal framework.

- Official networks or associations.

- Research programs.

- Financial instruments to support EPC.

- Barriers and drivers for increased use of EPC.

- Experiences with the EPC model:

- Summary and possible recommendations.

- Central Contacts in each country:

- Authorities and EPC experts.

- ESCOs/EPC providers.

- EPC Facilitators.

The last two chapters of the report are designated to comparisons and recommendations concerning EPC in all the Nordic countries.

- Comparisons of the Nordic EPC markets.

- Recommendations. 
In the final report presented in December 2015 we will, based on the input from EPC experts, the workshops and seminars planned in the autumn of 2015 present further and more detailed recommendations and possible cooperation projects between the Nordic countries. 



\section{Denmark}

\subsection{The EPC market in Denmark}

\subsubsection{Short history}

Until the mid 2000s the EPC market in Denmark was rather limited and mostly focused on the industrial sector. However, since 2006 the market has had a significant growth based on a demand for energy renovation of municipal buildings. Energy requirements was introduced in building regulations from 1979, but approx. $75 \%$ of public buildings are constructed before 1979 and not living up to later requirements.

\subsubsection{Number of projects}

All registered EPC projects have been within the public sector. As of 2015 around 30 out of 98 Danish municipalities are dealing with either preparation or implementation of EPC projects. From the first EPC project in 2007 there has been an average of 4 projects a year, and there was a boost in the market from 2011-2013.

\subsubsection{The EPC Providers}

Approx. 20-25 companies are offering ESCO services, most of them as sub suppliers to the EPC providers. In relation to existing contracted EPC projects 8 ESCOs were identified as EPC providers. Two large EPC providers, Siemens and Schneider Electric DK, has until now dominated the marked and share one third of the market between them. The rest is shared by a handful of EPC providers. Moreover Energy Supply Companies have started to enter the market in light of the governmental Energy Efficiency Obligation scheme (EEO), which were in place in Denmark prior to the European Energy Efficiency Directive (EED). 


\subsubsection{The EPC Clients}

In 2012 almost all Danish municipalities were in the process of planning, ${ }^{4}$ analysing or implementing energy renovations of municipal buildings - mostly by means of internal resources. This take place either as an integrated part of the overall building renovation schemes or through models that concurrently allocates resources for energy renovations. Municipal staff typically manages these projects and hence hire energy consultants and order equipment for installation themselves.

The municipalities sending their energy renovations task out in a tender (approx. 30) as an EPC project have a need to implement a large number of EE measures in a relatively short time, and find that the most professional way to do this is through an EPC project. In Denmark the most comprehensive measures in public buildings are carried out in EPC projects, which also lead to higher energy savings than projects carried out by means of internal resources. The measures in EPC projects are implemented faster - hence the savings also come faster.

Table 1: EPC versus internal municipal solutions

\begin{tabular}{lrr} 
& Internal municipal solutions & EPC projects \\
Practical implementation time (years) & & 2.2 \\
Amount spent over 5 years (EUR/m ${ }^{2}$ ) & 14.4 & 45.2 \\
Energy savings (percentage) & $13.8 \%$ & $21.1 \%$ \\
\hline
\end{tabular}

Source: Danish Council for Public-Private Cooperation.

The first three municipalities that launched tenders and implemented EPC projects in Denmark (2006-2008) started up the cooperation network called "ESCOmmuner" (EPC municipalities). This cooperation was supported by EU to disseminate the EPC experience to other municipalities.

Good experiences made in one of the first municipalities implementing EPC projects from 2008-2012, Middelfart, ${ }^{5}$ made for a success story that gave the market an extra boost.

In 2010 ten municipalities had signed an EPC contract. Subsequently a range of other municipalities looked into possible EPC projects through pilot projects and/or offers from ESCO companies.

\footnotetext{
${ }^{4}$ Survey carried out by the Danish Council for Public-Private Cooperation in 2012.

5 The municipality of Middelfart implemented energy saving measures in ca. 100 public buildings. While, the guaranteed savings were rather high (21\%), actual results have showed savings up to $24 \%$ of the total energy use.
} 
Mainly small- and medium sized municipalities, that have the highest need for external resources, use the EPC approach. Until now the municipality of Frederiksberg is the only larger municipality in Danish scale, with a full-scale EPC project while other larger municipalities are evaluating the concept through pilot projects and pre-investigations. ${ }^{6}$ Several of the municipalities that have already entered into EPC projects are now considering a second wave of EPC projects.

\subsubsection{The EPC Facilitators}

In the Danish EPC projects, a facilitator usually supports the EPC client. There are both active and potential EPC facilitators in Denmark helping the municipalities preparing contracts, launching the tenders, offering technical advice and working as mediators between the client and the provider. There are currently four main facilitators in the Danish market. ${ }^{7}$

\subsubsection{Summary}

The experiences are mainly good, even if there are still some scepticism and lack of knowledge in some municipalities. The figure below shows how the projects have developed over the last 8 year.

\footnotetext{
Duilding Research Institute.

${ }^{7}$ Kuben Management, Cowi, Rambøll, Dansk Energi Management/Esbensen.
} 
Figure 1: EPC development in Denmark

EPC development in Denmark:

Moving from first to second/third transparense

generation of EPC projects

\begin{tabular}{|c|c|}
\hline $\begin{array}{l}\text { First generation of EPC projects in } \\
\text { Danmark }\end{array}$ & $\begin{array}{l}\text { Next generation of ESCO projects in } \\
\text { Danmark }\end{array}$ \\
\hline Volume up to 3 MEUR & Increasing volume; 6 - 20 MEUR \\
\hline $\begin{array}{l}\text { Limited to public buildings and the 'low hanging } \\
\text { fruits' of building measures }\end{array}$ & $\begin{array}{l}\text { Have developed to become holistic (including } \\
\text { issues like building envelope, indoor climate and } \\
\text { expanding to other areas like public lighting) }\end{array}$ \\
\hline $\begin{array}{l}\text { The guaranteed energy savings from the ESCO- } \\
\text { supplier were usually in the range of } 15-25 \% \\
\text { (for the entire contract period) }\end{array}$ & $\begin{array}{l}\text { The guaranteed energy savings from the ESCO- } \\
\text { supplier has increased to } 20-30 \% \text { (limited to 3-5 } \\
\text { years, with option for expansion) }\end{array}$ \\
\hline $\begin{array}{l}\text { The pay-back period of the implied measures } \\
\text { was } 8-10 \text { years }\end{array}$ & $\begin{array}{l}\text { The pay-back period of the implied measures has } \\
\text { increased to } 15-20 \text { years }\end{array}$ \\
\hline $\begin{array}{l}\text { The Baseline - Energy data basis was often } \\
\text { insufficient }\end{array}$ & The Baseline - Energy data basis has improved \\
\hline $\begin{array}{l}\text { The projects are own financed by the client } \\
\text { (municipality) }\end{array}$ & $\begin{array}{l}\text { The projects are own financed by the client } \\
\text { (municipality) }\end{array}$ \\
\hline
\end{tabular}

\subsection{National characteristics}

\subsubsection{The national EPC model}

The prevailing EPC model in Denmark includes improvements of the building envelope. The common method is pooling of buildings combined with a long contract period of at least 10 years. Hence the savings from the low hanging fruits can be used to pay for measures with a longer payback time. The ESCO companies generally assess that this requires a project volume of minimum $40-50,000 \mathrm{~m}^{2}$ and preferably a uniform building stock. The average building volume in the last years are $130,000 \mathrm{~m}^{2}$.

\subsubsection{Legal and financial support schemes}

The EPC projects are supported by the general favourable lending conditions for municipalities. In addition to the availability of loans with low interests, municipalities have been exempted from existing budget limitations in relation to energy renovations. This has opened up for relatively large projects where the accumulated energy savings are used not 
only to cover the EE investments, but also to renovate municipal buildings, including deep renovations.

\subsubsection{A typical EPC project; sector, size, savings}

The market development is characterized by an increasing project size to include deep renovation measures and RES measures. Subsequently, the contract period has increased from 5-8 years within the first projects and up to 20 years within the last projects.

The average size of the first 10 projects indicated below: ${ }^{8}$

- Number of buildings: 74 .

- Building area: $127,000 \mathrm{~m}^{2}$.

- Contract size: MEUR 5.9.

- Investment: $50.3 \mathrm{EUR} / \mathrm{m}^{2}$.

- Guaranteed energy savings: $21 \%$.

\subsubsection{The most recent projects}

The more recent projects project has a project size up to approximately MEUR 20 and some even aims at guaranteed energy savings closer to $30 \%$. User behaviour is increasingly taken into account to increase savings without increasing investment costs.

\subsubsection{Upcoming official Danish Standard for EPC}

Despite increasing confidence in the EPC concept, there is still some room for improvements of contract models that efficiently regulates risks, responsibilities and disputes. The general Danish tender model is very well developed, e.g. when it comes to disputes, but adaptations in relation to the EPC concept is needed, especially the need for contracts that efficiently shares the risk and responsibilities between clients and providers. Hence, an official standard for EPC has been under development. A standard contract for EPC in public buildings was sent out on a public hearing in 2014 and is expected launched in the autumn of 2015.

${ }^{8}$ A survey done by Danish Building Research Institute. 


\subsubsection{Characteristics summed up}

What seems to be characteristic for the Danish projects is that they are relatively large and ambitious and include deep renovations. They are based on holistic solutions and overall economic calculations with the municipal energy- and climate plans, a renovation lag in municipal buildings and good financial conditions as primary drivers.

\subsection{Governmental strategies to boost the EPC market}

The EPC model have been promoted and encouraged in different national policy papers, and are considered an essential measure for meeting international as well as national goals on energy savings and $\mathrm{CO}_{2}$ reductions (including the European 20-20-20 goals).

There is no specific legal EPC framework, but some regulatory measures have been major drivers in the development of the EPC market. In the following, we list the most important regulations and schemes that have been positive governmental strategies driving the EPC market:

- The Covenant of Mayors:

- In recent years, the Covenant of Mayors (CoM) has been of increasing importance, currently about 40 municipalities has signed up for the CoM.

- The Climate Agenda:

- The climate agenda has been an important motivation for many municipalities, also in relation to voluntary agreements.

- EPC guideline:

- In relation to the complexity of contracts, an EPC guideline was issued in the beginning of $2013,{ }^{9}$ based on experience from the first Danish projects. One major issue in these guidelines is the need for flexibility. EPC projects can be of different character and clients have different demands and requirements. Therefore, this guideline aims for flexibility in the tender material, without violating legal tender requirements.

${ }^{9}$ The EPC guideline was issued by the Danish Association of Building Automation and the Danish Chamber of Commerce. 
- Energy Labelling:

- Energy labelling is a result of the transposition of the recast Energy Performance Building Directive. ${ }^{10}$

- The Danish Energy Efficiency Obligation scheme (EEO):

- The Danish EEO scheme was introduced prior to the European Energy Efficiency Directive (EED). It consists of an annual binding target for all energy distribution companies. The system encourages the collaboration or establishment of ESCOs.

- Information activities:

- Initiatives by governmental institutions such as workshops, guidelines and collection of knowledge and "best practice" etc. have contributed to promote the EPC concept.

- The National Energy Research Programmes:

- The National Energy Research Programmes has initiated a number of R\&D projects on EPC, including developing a suggestion for a standard contract on EPC etc.

- ESCO network:

- There is no real ESCO Association, but in general, the industry is rather proactive in the field. The Danish Confederation of Industries runs an ESCO network aiming at facilitating debate and matchmaking between companies that want to pursue the possibilities of forming EPC projects. ${ }^{11}$ There are other similar general cooperation networks such as Danish Energy Solutions, which is a cluster organization co-financed by EU funds and corporate members.

\subsection{Financial instruments to support EPC}

To encourage energy savings municipalities are allowed to take loans for energy renovations provided that measures suggested by the energy labelling is included. Normally renovations financed by loans would not be allowed, in order to keep the municipal taxes under control, but an exception is made for EE renovation. Municipal loans, guaranteed via the municipal credit institution "KommuneKredit" have low interest rates. The guaranteed savings in the EPC contract cover the mortgages on the

\footnotetext{
${ }^{10}$ Energy Performance Building Directive (2010/31/EU).

11 The premier lobbying organisation for Danish businesses on national and international issues.
} 
loan, and the municipality can therefore complete energy renovations as expense neutral (Danish Building Research Institute).

\subsection{Barriers and drivers for increased use of EPC}

The following main barriers and drivers are derived from the description of the Danish EPC market:

- Barriers:

- No particular legal framework for EPC.

- No coordinated and central effort to promote EPC further.

- No ESCO Association.

- Complexity of the EPC concept.

- No Danish standard for EPC.

- Lack of trust.

- Lack of insurance of long-term financing.

Regarding the last barrier, the exemption from budgetary limitations that allows Danish municipalities to get loans with low interest rates guaranteed by the government for EE renovation might not continue. This could result in a setback for EPC projects, as these loans are believed to be one of the main drivers for the EPC projects.

The major barriers seems to be the need to provide a coordinated effort to further promote the EPC concept for high quality projects, ensure long-term financing and develop standard procedures to ensure flexibility and transparency.

- Drivers:

- The municipalities own local initiative and commitment.

- The success of the first EPC projects.

- Loans with governmental guarantees.

- Upcoming Danish Standard for EPC.

- The uptake of the European Energy Efficiency Directive and its provisions in favour of EPC.

- General strong energy efficiency framework.

- The ESCO Network established by the Danish Confederation of Industries. 
As indicated above the Danish municipalities have been the locomotive in the rapid development of the Danish EPC market. The need for energy renovations of municipal buildings together with good loaning conditions and the general climate agenda have motivated municipalities to use the EPC concept.

\subsection{Future possibilities for EPC in Denmark}

Based on the municipal experience EPC projects are emerging in stateowned buildings and investigations are currently made to find suitable approaches to expand this. Social housing is a policy priority, but due to various barriers the initiatives on the ground are few. There is hope that a pilot project (BoVest in Albertslund) can pave the way for a broader use of EPC in social housing. Another market segment is the residential building sector. Some utilities have developed concept offers for house owners, sometimes in partnership with municipalities. These efforts are backed by the Energy Efficiency Obligations that the utilities are subject to.

Denmark traditionally has a very well-developed business culture, which is an important factor in an EPC project. The successful project would need to create a win-win situation, based on an effective partnership between the Client and the ESCO. This partnership has been a cornerstone in most of the Danish EPC projects, but there is still a limited experience to draw upon, especially on the client side. As the EPC market is growing and new ESCOs enter market, this will be the case also for new EPC providers.

A relevant organisation at Governmental level in this context is "Council for Public-Private Cooperation", which is established by the Government to support competition for public sector contracts and to promote cooperation between public authorities and private companies.

To meet the uncertainties regarding the possibilities for low interest loans several financial options are discussed, such as third party financing schemes.

The market for EPC in public buildings has stagnated somewhat in the last two years. On the other hand, the market for EPC in public hospitals seems to be growing. In a Business facilitation seminar for EPC in June 2015 EPC experts in Denmark predict a coming growth also in the private sector. 


\subsection{Central contacts Denmark}

- Danish Public Authorities:

- Energistyrelsen, the Danish energy agency, www.ens.dk

- Bygningsstyrelsen, the Danish building \& property agency, www.bygst.dk

- Danish EPC Facilitators:

- Kuben Management, www.kubenman.dk

- Cowi, www.cowi.dk

- Rambøll, www.ramboll.dk

- Dansk Energi Management \& Esbensen, www.dem-esb.dk

- Danish EPC providers:

- Caverion, www.caverion.dk

- Danish Energy Management, www.dem.dk

- Dong Energy, www.dongenergy.dk

- Energi Midt, www.energimidt.dk

- Glenco, www.kemp-lauritzen.dk/glenco

- Honeywell, www.honeywell.dk

- NCC Constructions, www.ncc.dk

- Schneider Electric Buildings Denmark, www.schneiderelectric.com

- SEA NVE, www.seas-nve.dk

- SE Big Blue, www.sebigblue.dk

- Siemens, www.siemens.dk

- Skanska, www.skanska.dk

- Trefor, www.trefor.dk

- Verdo, www.verdo.dk 


\subsubsection{Denmark}

- Transparense report "D2.4 Country report on identified barriers and success factors for EPC project implementation - Denmark", by EC Network, November 2013.

- Transparense report "D2.5 Country Report on Recommendations for Action for Development of EPC Markets - Denmark", by EC Network, June 2015.

- Experiences with ESCO contracting in Denmark and abroad, MEMO, for The Danish Energy Agency by Rambøll, June 2014.

- Input from Nils Daugaard, EC Network.

- Presentations from the Danish energy agency, Energistyrelsen, June 2015. 



\section{Sweden}

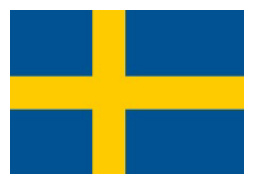

\subsection{The EPC market in Sweden}

\subsubsection{Short history}

The first EPC projects started up around 1990 by a handful of ESCO companies offering small EPC project directly to both private and public customers.

The EPC market in Sweden is well developed, in the sense that EPC as a business model has been implemented and adapted for a long time. The market has however been fluctuating for many years. In the early 00s, rising energy prices, renewed environmental concerns and focus on climate change generated growing interest in energy efficiency improvement and hence EPC. Customer financed EPC has been the main model.

Following the National Energy Efficiency Action Plan and good subsidy schemes for public buildings (KLIMP ${ }^{12}$ and OFFROT ${ }^{13}$ ), the EPC market in Sweden grew considerably from 2008. Several good municipal projects were implemented and the success stories spread via good governmental initiatives, providing information about experiences and financial grant schemes. This development came to an abrupt halt in 2009/2010 when the financial scheme OFFROT ended. This coincided with an EPC procurement process in Stockholm in 2009 were the dispute between the parties ended up in court. The dispute created mistrust in the EPC business model.

From 2010 municipalities and local regions could apply for governmental support for EE improvement measures from s program administered by the Swedish Energy Agency. The support for EE measures ended in 2014. Although being a financial support, it did not seem to boost

\footnotetext{
${ }^{12}$ KLIMP; Green governmental subsidy with up to $30 \%$ grants for green investments - closed in 2008. 13 OFFROT governmental financial scheme granting subsidies for EE investments (2005-2009) granted investment subsidies of up to $30 \%$ for a number of EEI actions (e.g. improved lighting, ventilation, control apparatus, building envelope) as well as conversion to RES (e.g. district heating, free cooling, photovoltaic). The targeted sector was public non-residential buildings (e.g. hospitals, schools, universities, administration offices, sports and recreational facilities, etc.) covering 63 million $\mathrm{m}^{2}$ of building area. In total, over the program period, the property owners were granted app. EUR 200 million.
} 
the EPC market, probably because it coincided with the financial crisis. During these years (2010-2014), the EPC market has been very weak.

At present, the market is very slow and few new projects have been procured in the last years. Data from the Transparense survey indicates that most of the ESCO respondents believe that the market for EPCs in Sweden had seen shown a slight or major decline over the last three years.

\subsubsection{Number of projects}

According to EEF, 14 the association for EE companies, there has been around 100 small and medium sized EPC projects in public sector in Sweden, even though there have been few newcomers in the last years. An estimation is that there has been none or 0-2 project per year in the last three years. The latest known EPC contract was signed in June 2015 between the municipality of Eskilstuna and Caverion.

EEF, the association for EE companies, is currently also gathering information and statistics from EPC providers in private sector and will be able to present the findings shortly.

\subsubsection{EPC providers}

There are currently mainly 5-6 companies offering EPC services in Sweden, some of which are international companies also providing EPC in other countries. The three main providers are Siemens, Caverion and Schneider Electric and between them they cover most of the Swedish market. Most of the ESCOs are primarily active in the public and governmental sector.

\subsubsection{EPC Clients}

Almost all known Swedish EPC projects has had public clients. An estimated $80-90 \%$ of the EPC clients are municipalities or regions implementing EPC in a pool of both service and office buildings. There are also a few EPC projects in private industry.

There have also been EPC projects in private sector, but they are not mapped in the same way as for public sector. In the last few years there has however been more activity detected in private than public sector.

\footnotetext{
${ }^{14}$ EnergiEffektiviseringsFöretagen, a common planform for companies working with Energy Efficiency and newly become the Swedish ESCO association.
} 


\subsubsection{The EPC Facilitators}

Among consulting firms some found a niche in supporting EPC customers with consultancy services related to procurement and project implementation, hence taking the role of EPC facilitators. To hire a facilitator is common when starting an EPC project. There is currently 5-6 EPC facilitators in the Swedish market, two of which are active. ${ }^{15}$

\subsection{National characteristics}

\subsubsection{National EPC model}

The building types in which EPCs were being carried out vary. The most common buildings subject to EPC services are public buildings (90\%) and offices (80\%). Only two ESCOs offer EPC services for industries.

A typical EPC project addresses both energy efficiency and quality improvement measures. The measures/technical areas most commonly included are building energy management systems, heating, ventilation/air conditioning (HVAC) and lighting efficiency and control.

An evaluation of 14 Swedish EPC projects in public sector in 2007, suggested variations in energy savings from between $17 \%$ to a staggering 66\%, indicating a substantial potential for energy savings by EPC projects. The most common investment outlay (value of the contract) is between MEUR 1 and 5, but some have been considerable larger.

More recent statistics (2015) by the EEF on EPC projects in public sector shows there has been approximately 100 implemented EPC projects in public sector from 2005-2014. The average length of the projects are 5-6 years and the average area covered about $120,000 \mathrm{~m}^{2}$. The average savings for these 100 projects was $18 \%$.

In principle, all savings are credited the EPC client in Sweden. The EPC provider are paid in full for the entrepreneurial work. After that, the client will pay a monthly fee for the follow-up work and this is the basis for the regulation of the savings guarantee.

${ }^{15}$ Manuel Swärd, Mersam, Magnus Klahr, WSP. 


\subsubsection{ESCO association}

Up until recently there was no clearly defined ESCO association in Sweden, which made it difficult for ESCOs to establish themselves as a unified EPC industry. A broader organization, EEF (Energieffektiviseringsföretagen = Energy Efficiency Companies), was a network for energy service companies in general, has recently developed into a Swedish ESCO association. They are now administrating the European Code of Conduct for EPC and are analysing how a certification of energy service providers could be realised. They have recently gathered statistics on EPC projects in public sector, and are currently doing the same for private sector.

\subsubsection{Financing}

In Sweden, the funding of EPC projects is almost always done by the customer, either by budgeted funds or through loans. EPC providers in Sweden provides third-party financing, but this is rarely the chosen model since public building owner can get better terms through own financing and better interests on bank loans. Kommuninvest, a municipal investment bank, is the most common bank used by municipalities for the implementation of EPC projects.

Results from Transparense survey, however, show the interesting fact that this bank usually do not ask for documentation of what investments municipalities will use the loans for. This could possibly be a potential for development of a green interest rate.

\subsubsection{Public procurement}

The Swedish public procurement act came into force in 2008. The act is supportive of and able to accommodate the procurement of EPC, but some experts' judge the practices as too complicated.

Procurement guidelines for EPC were issued by the Swedish Environmental Management Council in June 2009. Procurement models have also been produced by the Swedish Energy Agency, although these are not widely used. Some experts say there have been trust issues regarding these guidelines after the earlier mentioned procurement dispute in Stockholm. Still the success of many municipal EPC projects indicates that in general, EPC procurement is possible and that the problems are overcome on a case-to-case basis. 


\subsubsection{Support Schemes}

The removal of both the KLIMP (2004-2008), the OFFROT financial scheme (2005-2009) and later the financial support for EE improvement measures (2010-2014) seems to have brought a stop to the previous growth. The scheme regulations made no requirements about EPC, but there are clear indications that many of the EE actions were implemented through EPC projects.

The removal of financial support along with some bad experiences with the procurement law seems to have made clients sceptical to the model and entering into an EPC contracts might be perceived as taking a risk on both financial and legal levels.

\subsubsection{Complexity of the process}

In Sweden, the control and verification routines for building measures seem to be complex. The EPC clients tend to be involved in the implementation process regarding the choice of equipment and suppliers. Hence, this phase is quite long; consequently demand a lot of resources and can make it more difficult for the EPC providers to have full control over the guaranteed saving results. The takeover process is also reported to be quite complex following check-up lists were independent consultants are hired to test the quality of implemented measures where the EPC provider is often forced to do improvements if discrepancies are found.

Generally, the legal and administrative requirements for an EPC project in Sweden are quite high, and suffer from a lack of standardisation. As there is no "typical" type of contract, the EPC providers offer slightly different models and contracts. The EPC industry has largely been left on its own and had to rely on its own initiative to grow and become successful. The survey respondents in Transparense find the Swedish existing policies ineffective to very ineffective in boosting the EPC market. Some even stated that there are actually no policies in place. 


\subsection{Governmental strategies to boost the EPC market}

There is no specific legal framework for EPC in Sweden, but several directives and regulations support energy efficiency improvements, such as the Energy Efficiency Directive (EED) and the ECO Design Directive. Examples of Swedish adaptations to the above-mentioned directives or regulations/policy instruments that support energy efficiency improvement and EPC are described below.

\subsubsection{EU Building Directive ${ }^{16}$}

The directive may indirectly raise awareness of the potential for energy savings and thereby call for EPC projects in cases where the energy declaration shows poor performance.

\subsubsection{Energy Labelling}

Energy labelling is regulated in the EPBD and implies that a systematization of the energy performance of buildings should be done. This enables comparisons between different buildings' energy use.

\subsubsection{Upcoming laws for energy audits and energy certificates}

The Energy Efficiency Directive aims at promoting cost-effective improvement of energy end-use in the EU, including by promoting the market for energy services such as EPC, by a range of measures. Based on the directive the Swedish government has proposed a new law demanding large companies to do energy audits.

16 The Directive on Energy Performance of Buildings (EPBD directive, 2010/31/EU). 


\subsubsection{EE regulation}

There is a regulation requiring some authorities to make energy efficiency improvement actions (Regulation 2009:893). The measures are reported to the Swedish Energy Agency.

\subsubsection{Information activities}

To overcome property owner's lack of knowledge and understanding of the EPC concept a set of initiatives, mainly funded by the Swedish Energy Agency, was launched during the period 2005-2010 to gather market actors and disseminate good practice examples.

\subsubsection{National Research Programs}

A number of research initiatives and informal networks have been implemented in recent years to build knowledge on EPC. The NEEAP 2008 (SOU 2008:25 NEEAP) proposed to support the Forum for Energy Services run by the Swedish Energy Agency. This forum has however, been dormant for some time due to staff turnover and limited resources. The lifespan for the present European Energy Services Initiative (EESI) website is limited to the duration of the project.

\subsubsection{EPC Guidelines}

In the spring of 2009 the Swedish partially governmental organisation the Swedish Environmental Management Council issued guidelines on the procurement of EPC, and published a report on experiences of public procurement of EPC. These guidelines addressed previous uncertainties about procurement of EPC. The discontinuation of the EPC project in the City of Stockholm in 2010 meant further uncertainties about how to procure EPC in accordance with the Public Procurement Act, which in effect deflated the efficacy of these guidelines. 


\subsection{Financial instruments to support EPC}

There are at the present time no financial support schemes or grants supporting EPC implementations or EE measures in general, since the former support schemes (KLIMP, 2004-2008, OFFROT 2005-2009 and EE grant 2010-2014) were removed.

\subsection{Barriers and drivers for increased use of EPC}

The following main barriers and drivers are derived from the description of the Swedish EPC market:

- Barriers:

- Uncertainty about the Public Procurement Act.

- Discontinuation of public grants.

- Lacking continuity in information initiatives.

- Limited number of ESCOs.

- Lack of facilitators.

- Lack of knowledge, and knowledge asymmetries between clients and ESCOs.

- Lack of customer demand.

The two last barriers can be explained by the fact that the EPC market has been driven mainly by ESCOs and often clients have had limited knowledge the EPC process. ESCOs inform and offer to train clients, but this makes the clients dependent on ESCOs to some extent. This dependency may lead to a caution to embark on EPC projects.

- Drivers:

- Success stories.

- High saving potential established.

- Good energy statistics in the client organisation.

- Past financial schemes were working.

- Upcoming legal framework.

- Planned information activities (SEA/EEF).

- Upcoming statistics/overviews (EEF). 


\subsection{Future possibilities for EPC in Sweden}

Despite the EPC models' obvious potential and several success stories, the model is regularly struggling with weak market demand in Sweden, indicating both long-term barriers and occasional barriers dependent on specific framework factors, such as financial crisis, removal of specific policy support and financial support. This has strongly slowed the development of EPC down and customers are still reluctant to see EPC as a win-win type of contract.

The EPC market in Sweden is still by no means dead and newly contracted projects may lead to the positive attention and saving results that the market needs to awaken. In spite of prior difficulties and lack of public funding schemes tenders are made, contracts are signed and new initiatives taken to increase knowledge of EPC and trust in the EPC model.

In the framework of the EU project Transparense the following recommendations to promote growth were suggested, based on surveys and expert opinions of the Swedish EPC market: ${ }^{17}$

- Increase knowledge of EPC among potential clients.

- Establish a Client forum for EPC.

- Strengthen high level education on energy services.

- Own webpage for EPC.

- Secure long term financial solutions.

Another possible route to overcome the trust issues between clients and providers is to promote the facilitators role. In particular, one could focus on their role as initiators of projects and their role as experts of the tender and negotiation phase. This would probably lead to a more ESCOneutral process and hopefully lead to the use of more uniform model documents. A facilitator taking the role as mediator might help the barriers of asymmetries of knowledge between clients and providers.

17 Transparense Survey 2013. 


\subsection{Central contacts Sweden}

- Swedish energy authorities:

- Energimyndigheten, The Swedish Energy Agency. Contact person for EPC: Anders Pousette, www.energimyndigheten.se

- EEF, EnergiEffektiviseringsFöretagen, the Swedish ESCO association. Contact person: Lotta Bången, www.eef.se

- Swedish EPC facilitators:

- Per Manuel Swärd, Mersam AB.

- Magnus Klahr, WSP Group Sweden, www.wspgroup.se

- Swedish EPC providers:

- Caverion, www.caverion.se

- Dalkia, www.dalkia.se

- Eneas Energy, www.eneasenergy.se

- Honeywell, www.honeywell.se

- Schneider Electric, www.schneider-electric.com

- Siemens, www.siemens.se

\subsubsection{References}

- Transparense report "D2.4 Country report on identified barriers and success factors for EPC project implementation - Sweden" November 2013.

- Transparense report "D2.5 Country Report on Recommendations for Action for Development of EPC Markets - Sweden".

- ESCO Market Report 2013, Paolo Bertoldi, the Joint Research Centre, the European Commission's in-house science service.

- EEF website, www.eef.se

- Input from Jenny Gode, IVL.

- Input from Anders Pousette, Energimyndigheten. 


\section{Norway}

\subsection{The EPC market in Norway}

\subsubsection{Short history}

There were EPC projects in Norway from between 1995, but before 2008 there were only sporadic occasions of EPC or similar projects, and the market response was low. Some pilot projects on outsourcing or result based contracts were initiated through EU/SAVE projects, mainly in the private sector, but the contents and contracts differ from the EPC concept as defined in this report.

Low energy prices in Norway result in low interest in energy measures in general, and the finance crisis in 2012/13 led to less interest from the banking sector. However, focus on climate both in media and in municipalities through climate plans over the last 5 years resulted in increased focus on energy use in public buildings, where EPC can be a strong tool. In addition, some EU projects (Eurocontract and EESI) were in place to promote knowledge on EPC, conduct training, initiate pilot projects and develop tools. In addition, the "Green municipalities" initiative by The Norwegian Association of Local and Regional Authorities, KS, 18 has played an important role in spreading information about the EPC concept and model, and in developing model documents. The national energy agency Enova SF has also been active in promoting EPC over the last few years. The focus has been on public buildings, with schools, offices and nursing homes as the main building types.

In 2013 development of a Norwegian Standard for EPC was started, with a working group consisting of representatives from energy authorities, market actors as well as legal representatives. The official standard for EPC was launched in April 2014. The standard covers the entire process from analysis of the buildings, the implementation of measures and regulation of parties' relationship in the guarantee phase. Having an official standard is important in promotion of EPC as it counteracts many of the barriers related to trust, public procurement and "outsourcing".

${ }^{18}$ Kommunenes Sentralforbund (KS). 
Most EPC projects introduced to the market since then have used the standard and its use is expected to increase in the future.

The Norwegian energy agency, Enova has since 2002 had a grant scheme for EE measures in buildings. Over the last years, they have seen that EPC projects cover larger pools of buildings, are more certain to be implemented, have higher savings and are implemented faster than other EE building projects in Norway. ${ }^{19}$ Hence, Enova have taken a successively more active role in promoting EPC as this increases their overall saving results. Besides arranging their own information events on EPC they have cooperated with KS and also participated on EPC seminars arranged by the EU-projects Transparense and EESI2020 and ESCOs all over the country.

As a result of the combined efforts described above the Norwegian EPC market has developed considerable over the last 3-5 years.

\subsubsection{Number of projects}

By the end of 2013 a total of 32 tenders for municipal EPC projects had been published. During the whole of 20146 EPC tenders were announced, all by municipalities, counties or pools of municipalities. The first half of 2015 have shown what might be called a boom in the Norwegian EPC market. By the end of July 201512 new EPC tenders was announced, which means that the total number of public EPC tenders is now 60 .

\subsubsection{EPC providers}

There are currently 6-8 active and experienced EPC providers on the Norwegian market, and usually around 5 bidders for contracts. ${ }^{20}$ Some local actors have also shown interest, but so far not been able to win a project. The ESCOs have a limited number of EPC personnel - and even less EPC experts, which is currently a barrier as the ESCO capacity for new projects run out. The lack of ESCOs has been an issue in particular in remote geographical areas. The building owners have complained that the competition is not sufficient. The ESCOs have limited capacity and are only interested in the best projects (most profitable, short travelling distances, highest potentials etc.).

19 Presentation by Øyvind Moe, Enova SF (May and June 2015).

${ }^{20}$ Schneider Electric Norge AS, Simens, GK (Gunnar Karlsen), AF Energi og Miljøteknikk, Caverion, NEE (Norsk Enøk og Energi AS). 


\subsubsection{EPC Clients}

Almost all known EPC projects in Norway have been in public sector and mainly in municipalities or pools of smaller municipalities. Norwegian counties have also been among the EPC clients. Some counties has also been active in promoting the EPC model for their municipalities in the form of information and training activities and even financial support for facilitation of new EPC projects.

\subsubsection{EPC Facilitators}

In Norway, there has been one active EPC facilitator in the market since the start of the first EPC projects. ${ }^{21}$ The EPC clients in Norway are contacted by the EPC facilitator or contact him directly after having heard his presentations or been referred by other municipalities. The facilitator offers to assist in all necessary preparatory activities, prepare the tender documents, lead the negotiations with the ESCOs and prepare and set up the final contracts. He is also acting as a mediator in the implementation phase of the projects when needed.

\subsection{National characteristics}

\subsubsection{National EPC model}

EPC in Norway usually includes improvement of the building envelope, energy management systems, automation, HVAC, heating and lighting. Street lighting is also included in some resent contracts.

There are 428 municipalities in Norway and some of them very small in way of inhabitants but large in area. The national public procurement law is limited to MEUR 6. Hence, large or medium sized municipalities typically launch one EPC projects in their municipality. Some have also launched two projects. Smaller municipalities tend to pool together to launch one common project.

As for the rest of the Nordic countries, Norway has a good developed business culture. This has been the corner stone for the cooperation between the client and the provider with the experienced facilitator as a control mechanism for the client resulting in a uniform and foreseeable process. After having negotiated the contract, agreed on measures, in-

${ }^{21}$ Siv. Ing. Kjell Gurigard AS. 
vestments and the resulting savings, most of the risk for achieving the contracted savings is placed with the EPC provider. Subsequently the ESCO in question is given the necessary freedom to implement the measures. When implementation of measures is over the takeover process is most often done by certifications from the ESCO. The ESCO guarantee the savings throughout the life time of the project that varies from 7-18 years - most projects from 7-12 years. If overachievement occurs, in most projects, the savings are shared between the client and the provider in a prearranged split. This ensures that both parties have a strong incentive for good performance.

\subsubsection{Experienced EPC Facilitator}

The one Norwegian EPC facilitator has been active since the start of the first EPC project in Nedre Eiker municipality in 2006. This facilitator has taken part in several European EPC projects such as Eurocontract and EESI and has adapted the resulting model contracts and documents for Norwegian conditions making them steadily more trusted over the years. The facilitator has, in cooperation with Enova ${ }^{22}$ and $\mathrm{KS}^{23}$ promoted EPC through several seminars and presentations aimed at counties and municipalities.

As a result, almost all the project processes, from start to end have been unified and foreseeable for both clients and EPC providers. In July 2015 this one facilitator had prepared 57 of totally 60 EPC projects on behalf of Norwegian municipalities.

The fact that there is only one successful facilitator on the market has been a bottleneck and new energy consultants are now showing interest and educate themselves to become future facilitators in the market.

A new facilitator recently prepared one project and two municipalities have prepared projects themselves. In the recent EPC project launched by a new facilitator where the contract model used differed from the Norwegian Standard and there was no split of savings in case of overachievement. The project is currently at a standstill due to a dispute over mistakes made in the tender procedures. So far, this single incident is not believed to have harmed the market.

\footnotetext{
22 The Norwegian energy agency.

${ }^{23}$ The Norwegian Association of Local and Regional Authorities.
} 


\subsection{Governmental strategy to boost the EPC market}

There is no legislative enforcement of energy efficiency or EPC in Norway. There are no demands on energy use in existing buildings, only in new buildings through building regulations. Public administrations have had few formal incentives to implement energy saving or climate measures. Strained economies, lack of knowledge and time and organisational issues have resulted in little focus on energy.

Due to low energy prices and excess hydro power energy saving in Norway has not traditionally been high in focus. After the deregulation of the energy market in 1991 various efforts have been put into energy saving, but there are still large potentials. In 2001 the national energy agency Enova SF was funded. They have introduced several campaigns and grant programs aimed at both heat production and energy saving. No major focus has however been put on EPC as a tool, but over the last couple of years Enova has supported training and marketing of EPC as a model.

\subsubsection{National Standard for EPC}

The main legislative framework for EPC in Norway is the national standard (NS6430) for EPC contracts. This is originally based on model documents and guidelines developed in former EU-projects and later strongly promoted by KS. The Norwegian Standard is now used in almost all public tenders.

\subsubsection{Information Activities}

The national energy agency Enova SF has in the last years taken a successively more active role implementing dissemination activities (see next section).

The municipal Climate plans are also important as they usually describe objectives for energy saving in public buildings. EPC can be a tool to reach these goals.

There is no ESCO network or association in Norway. To our knowledge, a network or association has not been discussed or regarded as a need by the ESCOs themselves. The market is relatively small and transparent. 


\subsection{Financial instruments to support EPC}

The financial model of the KBN (state owned municipal bank) with "green interest rates" for energy efficiency investments have proven very successful. Neither the financial sector nor the ESCOs have been able to compete with this solution, which is used by all projects tendered over the last few years. As a result, there are no significant financial barriers for public building owners in Norway with relation to project investments. The administrative costs (project identification/preparation, procurement, management and evaluation) can however still be an issue in strained municipalities.

Enova SF has grant programs for energy efficiency measures in general. These present no major driving force for EPC, but is seen as a positive element in decision-making processes (politicians are positive towards national grants). The grant program focuses on non-profitable measures and market development, which can influence the selection of measures in the EPC project towards including more "high hanging fruits".

\subsection{Barriers and drivers for increased use of EPC}

The following barriers and drivers have been identified as the most important for diffusion of EPC in Norway (in random order):

- Barriers:

- Lack of incentives to implement energy efficiency measures (low energy prices, no regulations).

- Lack of experienced project facilitators.

- Lack of available and experienced ESCOs.

- Lack of knowledge of EPC both among municipalities and potential EPC providers.

- Lack of documented experiences and success stories (decreasing but still important).

- Complicated tendering and contracting process (legal/procurement, technical issues).

- Insecurity about legislation and framework (decreasing with new standard).

- Lack of capacity (time and knowledge).

- Too good to be true? 
- Drivers:

- The official Norwegian Standard for EPC - increased use and promotion.

- Involvement and promotion of EPC by the authorities (e.g. Enova).

- Financial grant scheme for EE measures.

- Marketing and training seminars for EPC.

- Success stories - promotion of good practise examples.

- Active project facilitator.

- Standard contract documents and guidelines tested and adapted for many years.

- Increased climate focus.

\subsection{Future possibilities for EPC in Norway}

The fact that there has been mainly one facilitator in Norway has brought some advantages, in the sense that all EPC project model documents and later the official standard have been tested and adjusted according to experiences over several years. Tender documents used are the same for all and it is easier for ESCOs to design new project proposals and calculate the guaranteed savings.

The clients trust the ESCO to make the right choices regarding the purchase of equipment and implementation of measures, since the main risk rests with the ESCO. The takeover procedures are hence not very complex.

The following measures are recommended to increase the use of EPC in Norway:

- Promotion of success stories.

- Promotion of the official standard for EPC.

- Increased number of EPC facilitators and providers.

- Continue marketing of EPC for private and public building owners.

- Joint national EPC website with information and overview of market actors.

- Establish tools and model documents for private sector. 
The EPC market in Norway is expected to increase further in the years to come. Good experiences and documentation of results is likely to increase the demand. The market actors and procedures have become more professional and finally yet importantly, the national energy agency Enova has taken a leading role in increasing knowledge and promoting EPC-projects to potential public clients all over Norway.

\subsection{Central contacts Norway}

- Authorities:

- OED, Olje og Energidepartementet, www.oed.dep.no

- Enova SF, The Norwegian energy agency. Contact person: Tor Brekke, www.enova.no

- Kommunenes Sentralforbund (KS). The Norwegian Association of Local and Regional Authorities, www.ks.no

- Norwegian EPC Facilitators:

- Kjell Gurigard, Siv. Ing. Kjell Gurigard AS, www.gurigard.com

- Tor Mjøs, Norconsult AS, www.norconsult.com

- EPC providers:

- AF Energi og Miljøteknikk AS, www.afgruppen.no

- GK, www.gk.no

- Caverion, www.caverion.no

- Siemens, www.siemens.com

- Schneider Electric Norge AS, www.schneider-electric.no

- Norsk Enøk og Energi AS (NEE), www.nee.no 


\subsubsection{References}

- Transparense report "D2.4 Country report on identified barriers and success factors for EPC project implementation - Norway" November 2013.

- Transparense report "D2.5 Country Report on Recommendations for Action for Development of EPC Markets - Norway" August 2015.

- Input from national EPC expert/facilitator Kjell Gurigard.

- KS/Kommunenes sentralforbund web site: www.ks.no

- KNB/Kommunalbanken web site: www.kommunalbanken.no

- Presentation by Øyvind Moe, the Norwegian energy agency, Enova SF in the spring of 2015.

- Presentations and updated data form Kommunalbanken Norway, $\mathrm{KBN}$, the national municipal bank lending to the local government sector.

- Presentation by Siv. Ing. Kjell Gurigard, May 2015.

- Input from Thea Marie Mørk, NEE (Norsk Enøk og Energi AS), www.nee.no 



\section{Finland}

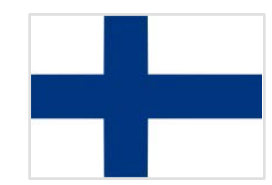

\subsection{The EPC market in Finland}

\subsubsection{Short history}

In Finland the first EPC projects started around 2000. In the beginning the market was dominated by smaller projects in private sector focusing on a few EE measures in only one or a few buildings. The projects had a short payback time and project period. In the last few years the projects has developed into small to medium sized projects in public sector following a similar model as in the other Nordic countries.

There are currently no statistics or register documenting EPC projects. An ESCO project register was established and run by the Finnish energy agency, Motiva, from 2004 to 2009, but it is now inactive. It seems the reason the register has not been followed up, is the fact that it was voluntary and hence did not give a complete picture of the EPC market. Another reason is that the market has seen a slight decline and that some EPC providers did not achieve the same saving results as in the earlier years. They were therefore reluctant to register these projects. It is also important to mention that it is more difficult to follow up and register projects in private sector. This is of course the case in all the Nordic countries, but extra worth mentioning when there is reason to believe it is a considerable part of the market, as in Finland.

In the first years, more than half of the projects were implemented in the private sector. The majority of public buildings documented were either sport halls or ice rinks. The annual savings for the registered projects vary between 200-33,000 MWh, depending on the character of the building and the implemented measures. The contract periods varied from 2-5 years. The measures presented in the register includes energy savings in industrial production and factory systems, urban sports halls HVAC systems, as well as transformation to renewable energy sources.

While public sector offers a larger saving potential, and the experiences from earlier projects successfully develop the market, a few projects have also faced substantial problems and affected the whole sector. Some projects were postponed or cancelled due to appeals to the Market Court. As a response, Motiva prepared a procurement guidance 
for EPC-projects in co-operations with municipalities and EPC providers. The guidance was published in 2012. Motiva continues to promote the guidelines.

\subsubsection{Number of projects}

The above mentioned register entails approximately 60 EPC projects. In the recent years the development has turned in favour of the public sector. Since 2009 there have been around 15 projects in properties owned by municipalities (Motiva).

It is hard to estimate the total number of EPC project up until now, but an educated guess by Motiva would be around 80 projects from 2009-2015 with increasingly more representation from public sector in the latest years.

\subsubsection{EPC clients}

The private EPC clients are mostly small building owners, industry and factories. The latest and most promising clients are municipalities. For these projects, the trend is that they are larger in both size and savings, they include pools of buildings and the contract period is usually around 5-10 years.

\subsubsection{EPC providers}

There are now around 7-10 ESCOs ${ }^{24}$ offering EPC projects in Finland. Some of these belong to large international firms who implements EPC projects also in other Nordic and European countries.

\subsubsection{EPC facilitators}

In several cases, building owners have used energy consultants as EPC facilitators. The number of active facilitators is not known. 


\subsection{National characteristics of EPC - short description of the model}

The Finnish EPC market is characterised by smaller projects in both public and private sector. The market can be described as new and under development and has had a slight growth, both in project size and number in the public sector during the last years.

The private EPC clients tend to be building owners entering into smaller contracts in one or just a few buildings - often focusing on a few very profitable EE measures.

The municipal projects are now somewhat larger, longer and implemented measures covers the building envelope, lighting, HVAC and EMS, but among them there has also been separate small projects targeting merely sport halls or street lighting. Behavioural elements seem to be a part of most projects in the public sector. Municipalities have the benefit of being trustful clients that can engage in long-term contracts and they have a steady and predictable energy consumption.

Finnish EPC project often include behavioural elements and building users are involved in the energy savings.

One of the latest EPC projects, implemented in the City of Vantaa included 15 buildings with a building area of $83,000 \mathrm{~m}^{2}$. The investment volume was MEUR 1.5 and the annual savings estimated to EUR 200,000, making it a small to medium sized EPC project. It would not be accurate to call it a "typical" project, since the number of projects in the latest two-three years have been very limited. The city of Vantaa received the annual prize for Sustainable procurer in 2014 for this project and it has been widely disseminated both in Finland and in the EU.

There are two main financing models. In the guaranteed savings model there are monthly fees paid to the ESCOs to cover the investments, with a short payback time of about 2-5 years. The ESCOs promise that monthly fees are invariably smaller than the savings achieved in the same period, takes over the risk and responsibility of the installed equipment, and guarantees the savings.

In public sector, it is more common that the municipalities finance the projects themselves through loans as they are able to get better interest rates than the service providers. Risk, responsibility and contracted guarantees are given by the ESCOs as for private sector.

However, in the City of Vantaa case the monthly fees are paid from the same budget as the energy costs, thus, the project does not impact the city's investment budget. 


\subsection{Governmental strategies to boost the EPC market}

\subsubsection{Information to market actors}

Motiva has had an annual project ordered by the Energy Authority to inform service providers and potential clients about the EPC concept. General marketing activities are undertaken including development and dissemination of material and guidelines for implementation and EPC contracting. Motiva also promote the EPC concept through dissemination of best practice examples.

\subsubsection{Guidelines and Contract models for EPC}

On behalf of the Ministry of Employment and Trade, Motiva prepared guidelines and contract models for EPC projects for both the private and public sector. The models, intended as templates, include guidelines on project planning and implementation of an EPC project. Guideline in possible funding models, both EPC providers funding the project and a client self-financing model are also available on Motiva's website.

These guidelines do not include model documents for public tenders of EPC.

\subsubsection{Upcoming statistics on EPC projects}

To monitor and map the EPC market in Finland Motiva are in discussions with the Energy Authority about the possibility to distribute questionnaires to collect information and statistics about EPC projects that have received EPC/EE subsidies/financial support. During 2013 and 201415 EPC projects received funding of totally EUR 2.87 million from the Ministry of Employment and Economy.

\subsubsection{Guidelines for large procurements}

Motiva published in 2012 guidelines for the procurement of large public the EPC projects, together with the representatives of the municipalities and ESCO companies. 


\subsubsection{Possible renewing the EPC project register}

Motiva is currently considering further development of the EPC project register. As a first step they will contact market actors to ascertain the benefits and necessity of the registry.

\subsubsection{Green Growth through Public Procurement}

Motiva recently received funding from the Nordic Council of Ministers (Äk-Näring) to a project called Green Growth through Public Procurement. One task is to build a Nordic network of public procurers and spread the knowledge and experiences in different innovative procurements. EPC might be one issue that will be dealt with in this project. Motiva is the co-ordinator of the project.

\subsection{Financial instruments to support EPC}

\subsubsection{Governmental financial scheme}

The Ministry of Employment and Economy has a strategy to grant subsidies for energy efficiency investments, both for EE measures in general and for measures included in EPC projects. EPC projects may be eligible for a financial grant of up to $20-25 \%$ of the investment cost for EE measures. The Centres for Economic Development, Transport and the Environment are administrating the grant subsidies for EPC-projects.

The EPC concept is also supported by what seems to be general favourable financing conditions for municipalities.

\subsection{Barriers and drivers for increased use of EPC}

- Barriers.:

The following main barriers are derived from the description of the Finnish EPC market:

- Lack of knowledge of the EPC model.

- EPC Guideline not promoted/implemented ("MotivaESCO concept").

- Complexity of the tender procedures/procurement process.

- Lack of model tender documents. 
- Lack of recent statistics and documentation of results.

- Few success stories.

- Lack of EPC facilitators and more marketing needed of those available.

- Drivers:

The following drivers are derived from the description of the Finnish EPC market:

- Information activities (Motiva).

- Governmental financial support scheme.

- Guidelines for procurements.

- Possible renewing of the EPC project register.

- Some recent projects might serve as Best Practise examples.

\subsection{Future possibilities for EPC in Finland}

The EPC/ ESCO concept and service model is still quite unknown in Finland. The contractual model and the complexity of the procurement process pose a challenge, especially for larger municipal projects. Municipalities need increased knowledge about the EPC concept, the technical aspects included and in procurement and contract law.

A few EPC facilitators are available, but the need for more information about the different stakeholders in EPC projects and promotion of recent successful projects are detected. Motiva will most likely play an important role in this respect.

In general the EPC market in Finland can be described as young, but growing. The market seems healthy and benefits from relatively stable governmental support in the form of guidelines, information activities and financial subsidies. New actions to promote EPC in the public sector and development of model tender documents are under planning. With the healthy Finnish business culture at the core, there should be good possibilities for a continuous market growth. 


\subsection{Central contacts Finland}

- Authorities:

- Energiavirasto, the Energy Authority in Finland, www.energiavirasto.fi

- Motiva Oy, the governmental company in resource efficiency. Contact person: Isa-Maria Bergmann, www.motiva.fi

- Ministry of Employment and the Economy, www.tem.fi

- The Regional Centres for Economic Development, Transport and the Environment, www.ely-keskus.fi

- Association for Energy Efficiency Services:

- Energiatehokkuusala Ry, www.energiatehokkuusala.fi

- EPC providers; (ESCOs):

- Are Oy, Harri Launo, www.are.fi

- Caverion Oyj (ent. YIT Kiinteistötekniikka), Teppo Manninen, www.caverion.fi

- Enegia Oy, Kalle Myllyaho, www.enegia.fi

- Foster Wheeler Energia Oy, Matti Nikander, www.fwc.com

- LeaseGreen Group Oy, Tomi Mäkipelto, www.leasegreen.fi

- Suomen Lämpöpumpputekniikka Oy, Juhani Malkamäki, www.lampoassa.fi

- Schneider Electric Finland Oy, (ent. TAC Finland Oy), Jan Mattsson, www.schneider-electric.fi

- Siemens oy.

\subsubsection{References}

- Motivas web site: www.motiva.no

- Input from Isa-Maria Bergmann, Motiva Oy.

- ESCO Market Report 2013, Paolo Bertoldi, the Joint Research Centre, the European Commission's in-house science service. 



\section{Iceland}

\subsection{The EPC market in Iceland}

There have been few or no EPC projects in Iceland so far according to ORKUSETUR, the Energy Agency Iceland.

The two main reasons for this are that Iceland is already carbon free in both heat- and electricity production and that both these energy sources are inexpensive. $90 \%$ of heating for buildings are covered by geothermal energy and $9 \%$ by hydro power. That leaves only $1 \%$ to be heated by fossil fuels. Geothermal energy is extremely cheap compared to prizes in the rest of Europe, and only $10-30 \%$ of the costs for fossil fuel heating in Iceland. Hence, energy cost savings with a reasonable payback time is hard to achieve. In addition to this geothermal energy is green energy with no $\mathrm{CO}_{2}$ emissions savings when reduced.

There are therefore few, if any environmental or economic incentives for energy saving and hence EPC in the building sector in Iceland.

Some energy service companies offer energy checks for heating, but savings are rarely significant unless they detect faults like leaking or system failures, like snow melting during summertime. They can therefore not guarantee savings in accordance with the EPC model.

The same arguments are valid for electricity, as it is also quite cheap and carbon free and hence makes little room for the EPC concept.

\subsection{Future possibilities for EPC in Iceland}

So far, the only sector where steps towards a guarantee model have been made is the lighting sector. The switch from conventional lighting to LED systems has elements of cost savings, both due to electricity savings and a longer lifetime of the equipment. Lighting companies have been known to offer LED street lighting to municipalities in a cost model where the municipality will pay the same price as before the measure is implemented for a period, the lighting company will get the difference until the investment and installation costs are covered. There might be possibilities for larger projects more in line with the EPC model in the future within this sector. 
Another possibility, not yet explored, would be in buildings heated by electricity. This is the case for approximately $10 \%$ of households in Iceland. The heating costs in these cases are strongly subsidised by the government (around $600 \mathrm{GWh}$ in total, of which $350 \mathrm{GWh}$ subsidized), which in turn lead to a very limited energy awareness among the building users.

Figure 2: Subsidised heating prices

\section{Comparison on house heating prices}

The Iclandic government subsidises up to 40.000

$\mathrm{KWh} /$ year per home.

- USD mills/KWh

- 2009 figures

Sources: Mintstrv of Industers. Enerov and Tourtem

Source: Ministry of Industry, Energy and Tourism.

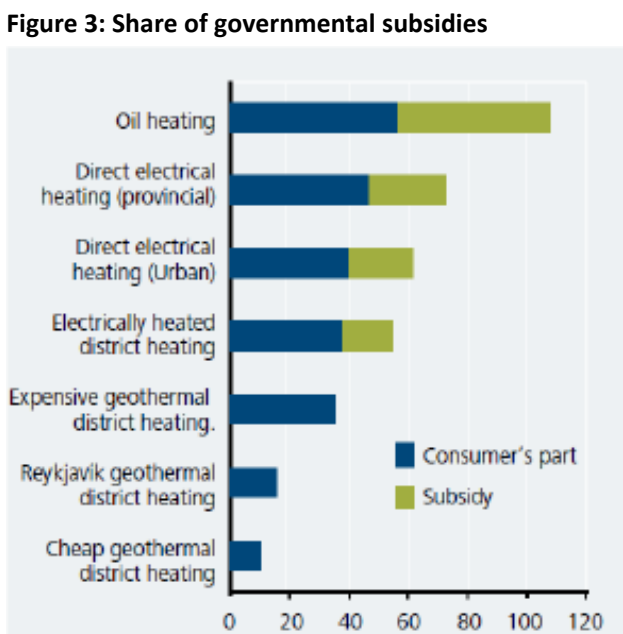


A shift in policy has now opened up for the possibility of direct funding from the government where subsidies are partly directed towards energy efficiency measures and investments. The ultimate aim for this development is to decrease the governmental subsidies for electric heating and hence reach economical savings for both the consumers and the authorities. This shift has led to investments like heat pumps, small hydro power plants, extra insulation and more energy efficient glazing. This might also make consulting companies able to implement measures according to the EPC model.

\subsection{Governmental strategies}

In 2006 the Energy Agency Iceland (Orkusetur) was established. Their main task is to give advice on energy saving and new options for building heating as an alternative to electricity to businesses and the general public. They also work to take steps towards a shift in the transport sector and other projects in the field of new energy sources.

The Energy Agency Iceland is aware of the EPC concept and continuously considers possible areas for EPC in the future.

\subsection{Central contacts Iceland}

- ORKUSETUR, Energy Agency Iceland (EAI). Contact person: Sigurður Ingi Friðleifsson, www.orkusetur.is 



\section{Comparison and Recommendations}

In the following, we will draw up some comparison between the countries, give some recommendations and list some possible cooperation projects to promote EPC in and between the Nordic countries.

The main market focus of this report has been on the development of EPC projects in public sector in the Nordic countries. This includes municipalities, regions, hospital and other buildings own by national authorities. For comparison, there are 98 municipalities and 16 counties in Denmark, 428 municipalities and 19 counties in Norway, 290 municipalities and 21 counties in Sweden, 336 municipalities and no counties in Finland and 76 municipalities and 8 regions in Island.

\subsection{Comparison}

\subsubsection{Most EPC projects implemented in public sector}

Typically, there were some small projects in private sector in the first few years after EPC was introduced to the Nordic markets. Now the trend is that public sector and especially municipalities have taken a solid lead. That being said it is more difficult to map projects in private sector in all countries, therefore there could be more projects existing. The highest number of EPC projects in private sector today is seen in Finland.

\subsubsection{Little or no financing by ESCOs in public sector}

It seems the financing is done by the client in all Nordic countries, at least in the public sector. 


\subsubsection{Main market drivers different in all Nordic countries}

The main market drivers are and have been different in the four Nordic countries.

In Denmark the clients, and more specifically the municipalities and there climate plans have been the main driving force and often municipalities themselves initiate the EPC projects.

In Sweden, the ESCOs have initiated contact with the clients, developed variations of the EPC concept and formed their own contract models. Hence they have been the main driving force; even though the energy authorities and facilitators have been visible market actors they have been less prominent.

In Norway, the one active and very experienced facilitator has been the initiator and spear point of almost all Norwegian EPC projects so far. The facilitator have been assigned by the authorities (Enova) to part take in regional and national promotion activities, and hence been able to get in contact with a wide range of potential customers.

Finland has had a different development where the governmental influence, especially in the public sector, seems to have been the decisive factor for most projects.

\subsubsection{The EPC model}

In Denmark, Norway and Finland the basic features of the EPC model seems to be the same and in line with the general European definition. ${ }^{25}$ Although there are variations of funding models for private sector, the principle of savings covering the investments are followed. All countries usually include a wide range of measures in the EPC projects, including the building envelope.

One variation has been found in Sweden, were as opposed to the other countries, the excess savings are not shared between client and provider. In principle, all savings are credited the EPC client in Sweden. This can be a barrier in the sense that EPC providers in Sweden do not have the same incentive to over-achieve performance as in the other countries.

${ }^{25}$ Point 1.2 , page 13 


\subsubsection{Size of investments}

The size of the EPC projects varies considerably in the Nordic countries. Denmark seems to have a starting point were the other three ends, with EPC investments from MEUR 6-20. In Sweden, there have been projects from MEUR 1-10, but the most common size is MEUR 1-5. The investment volume of the Norwegian EPC projects are limited to a maximum of MEUR 6 by the public procurement laws and most often the projects are between MEUR 3-6. The smallest project up until now is in Finland were the average size has been between MEUR 0.5-3, but the latest municipal projects have been up to MEUR 5.

The Danish municipalities are larger in the number of inhabitants. This explains some of the differences in the project size, but certainly not all.

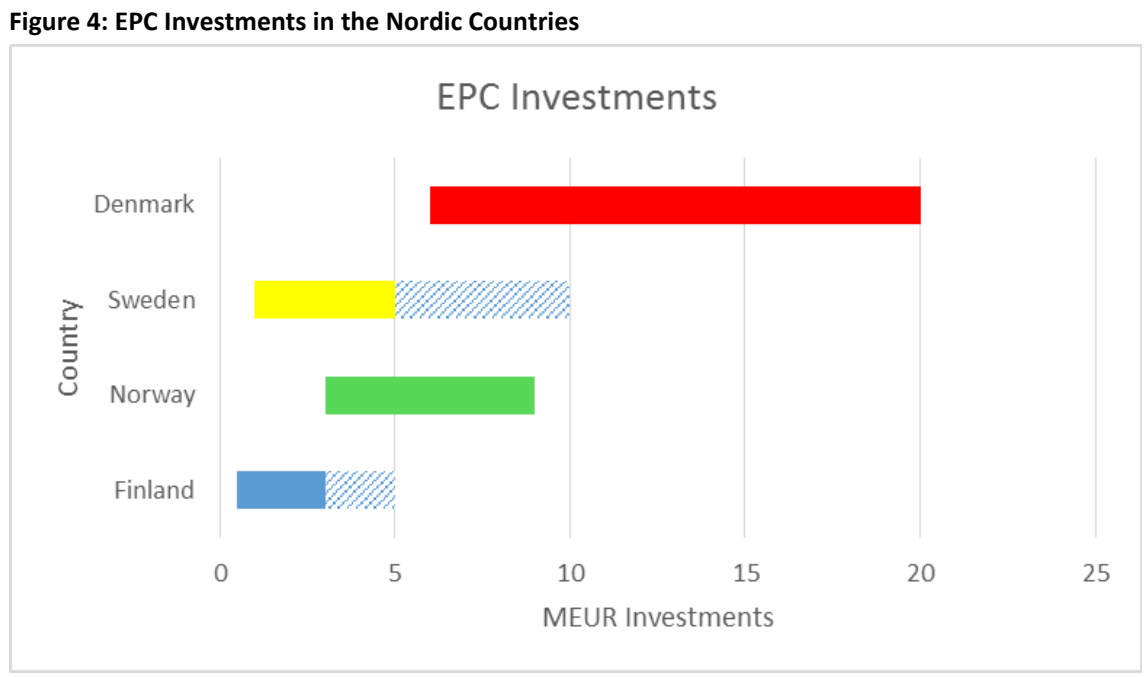

\subsubsection{Governmental financial schemes}

In Denmark, Norway and Finland some form of financial support is in place and it seems to be a driver of EPC, especially in the public sector. The financial schemes had the same effect in Sweden when in place, and a damaging effect on the market development when removed.

\subsubsection{Variation in complexity of $C \& V$ routines}

In Sweden, the control and verification routines for building measures are more complex than for instance in Norway and Denmark. The EPC clients also tend to be more involved in the implementation process re- 
garding the choice of equipment and suppliers. Hence, this phase is longer, demand more resources and can make it more difficult for the EPC providers to have full control over the guaranteed saving results. The takeover process in Sweden is reported to be more complex following check-up lists were independent consultants are hired to test the quality of implemented measures where the EPC provider is often forced to do improvements if discrepancies are found. Although this is the case in all entrepreneurial work in Sweden, EPC projects are often larger, include more buildings and hence these routines may be experienced as too time consuming and complex by EPC providers.

In Norway and Denmark the process is somewhat easier in the sense that after having agreed with the client on measures and the resulting savings, the ESCOs will make the decisions regarding the implementation from there on. The more complex routines for building control in Sweden seem to be a negative influence on EPC, all though undoubtedly positive in other regards.

\subsubsection{Model documents, guidelines and standards on EPC}

Model documents and guidelines have existed for a long time in Norway and were the basis for development of the official Norwegian Standard for EPC launched in 2014. This has had a positive influence and been regarded as a quality stamp of both the project model and the process. The same has been the case in Denmark, where an official Standard for EPC is expected this autumn. These documents have a vital importance due the complexity of an EPC project. The lack of these documents may explain many of the differences between Denmark and Norway on the one hand and Sweden and Finland on the other where there are no official standard and guidelines are of an older date and not very well known.

\subsubsection{Governmental dissemination activities by energy agencies}

In all four countries the energy agencies have a broad knowledge of the EPC concept and its advantages. In both Denmark and Norway the energy agencies seems to have taken a successively more active role as the concept were put to use and showed promising and fast results compared to step-by-stem implementation of EE measures. In Sweden and Finland the energy agencies have played a more active part in the initialisation of the EPC market. In Sweden the on-and-off governmental strat-

egies of both information activities and financial schemes have taken a 
toe on the market development with regards to customers trust in the EPC concept. In Finland, the public EPC market is simply still young, and will probably grow with the help of renewed governmental emphasis.

\subsubsection{Common market barriers and drivers}

Some barriers and drivers are common for EPC market in all the Nordic Countries. These are also found in most other European countries, and present to a smaller or larger degree depending on the maturity of the market.

- Barriers:

The most common barriers found in all the four Nordic countries are:

- No designated legal framework for EPC.

- Lack of active facilitators.

- Lack of good practice examples and documented results.

- Complexity of the EPC concept.

- Complexity of public procurement laws.

- Lack of knowledge, and knowledge asymmetries between clients and providers.

- Lack of trust.

- Too good to be true?

- Drivers:

The most common drivers found in all the four Nordic countries are:

- Good business culture.

- Financial support schemes.

- Active facilitator(s).

- Governmental information and promotion.

- Model documents, guidelines and official standards.

- Municipal energy- and climate plans.

- European energy legislations and directives. 
Many of the barriers are closely linked. It is natural for clients to ask themselves several questions; will all costs be covered by the savings? What is the catch? Are there some parts of the contract I have not understood properly? Will the ESCO in question be up and running for the whole duration of the contract?

An EPC project includes several areas of expertise such as technical engineering, economy, public procurement procedures, contractual law and sub sequential ethical issues. Legal frameworks, official standards, good practice examples, and active facilitators to control the process would be highly beneficial.

The good business culture already present in all the Nordic countries is the strongest driver to overcome most barriers.

\subsection{Overview of the Nordic EPC market - tables}

\begin{tabular}{|c|c|c|c|c|c|}
\hline & Denmark & Sweden & Norway & Finland & Iceland \\
\hline EPC started & 2006 & 1990-1995 & 1990-1995 & 2000 & \\
\hline $\begin{array}{l}\text { Number of } \\
\text { projects }\end{array}$ & 30 & 100 & $55-60$ & $\begin{array}{l}\text { 80-100 } \\
\text { (most small) }\end{array}$ & $\begin{array}{l}\text { No known } \\
\text { projects acc. } \\
\text { to EAI }\end{array}$ \\
\hline $\begin{array}{l}\text { Number of } \\
\text { projects } \\
\text { per year } \\
\text { (recent years) }\end{array}$ & 8 & $\begin{array}{l}\text { 1-2 public } \\
\text { private un- } \\
\text { known }\end{array}$ & $8-12$ & $\begin{array}{l}4-6 \text { public } \\
\text { private un- } \\
\text { known }\end{array}$ & \\
\hline $\begin{array}{l}\text { EPC providers } \\
\text { (ESCOs } \\
\text { impl. EPC) }\end{array}$ & 8 ( 25 bidders) & 3 ( 6 bidders) & 5 (7 bidders) & 7 (10 bidders) & \\
\hline
\end{tabular}


Table 3: National characteristics

\begin{tabular}{|c|c|c|c|c|c|}
\hline & Denmark & Sweden & Norway & Finland & Iceland \\
\hline $\begin{array}{l}\text { Legal frame- } \\
\text { work/ } \\
\text { obligations }\end{array}$ & NO & NO & NO & NO & \\
\hline $\begin{array}{l}\text { A typical EPC } \\
\text { project; }\end{array}$ & Large & Medium & Medium & $\begin{array}{l}\text { Small -> } \\
\text { Medium }\end{array}$ & \\
\hline - Sector & Public & Public & Public & $\begin{array}{l}\text { Private and } \\
\text { Public }\end{array}$ & \\
\hline - Size & $130,000 \mathrm{~m} 2$ & $120,000 \mathrm{~m} 2$ & $17-150,000 \mathrm{~m} 2$ & & \\
\hline $\begin{array}{l}\text { - Number of } \\
\text { buildings }\end{array}$ & $70-80$ (av.74) & & $\begin{array}{l}10-40 \\
\text { (av. 20) }\end{array}$ & $1-15$ & \\
\hline - Savings & $20-30 \%$ & $18 \%$ & $25-50 \%$ & $\begin{array}{l}\text { 200-33,000 } \\
\text { MWh annually }\end{array}$ & \\
\hline - Length & $15-20$ years & $5-10$ years & $7-18$ years & $\begin{array}{l}2-5 \text { years } \\
\text { recently } 5-10\end{array}$ & \\
\hline - Investments & 6-20 MEUR & 1-5 MEUR & 3-6 MEUR & 0.5-3 MEUR & \\
\hline $\begin{array}{l}\text { - Typical } \\
\text { measures }\end{array}$ & $\begin{array}{l}\text { Building enve- } \\
\text { lope, lighting, } \\
\text { HVAC, EMS, } \\
\text { heating, } \\
\text { automation }\end{array}$ & $\begin{array}{l}\text { Build envelope, } \\
\text { EMS, HVAC, } \\
\text { lighting }\end{array}$ & $\begin{array}{l}\text { Build envelope, } \\
\text { EMS, Automa- } \\
\text { tion, HVAC, } \\
\text { heating, } \\
\text { lighting }\end{array}$ & $\begin{array}{l}\text { Hist; Low hang- } \\
\text { ing fruits } \\
\text { Recent; Build } \\
\text { envelope/ } \\
\text { EMS/HVAC/ } \\
\text { lighting + street } \\
\text { lighting/sport } \\
\text { halls }\end{array}$ & \\
\hline - Financing & $\begin{array}{l}\text { Clients through } \\
\text { gov. Supported } \\
\text { loans }\end{array}$ & $\begin{array}{l}\text { Clients - no gov. } \\
\text { support at } \\
\text { present }\end{array}$ & $\begin{array}{l}\text { Clients through } \\
\text { gov. green } \\
\text { interest rates }\end{array}$ & $\begin{array}{l}\text { ESCOs or Cli- } \\
\text { ents - no gov. } \\
\text { support? }\end{array}$ & \\
\hline $\begin{array}{l}\text { The most recent } \\
\text { projects }\end{array}$ & 2015 & $\begin{array}{l}2015 \text { (before } \\
\text { that 2011?) }\end{array}$ & 2015 & 2014 & \\
\hline $\begin{array}{l}\text { Model docu- } \\
\text { ments }\end{array}$ & $\begin{array}{l}\text { Official guide- } \\
\text { line ('13) } \\
\text { Standard in } \\
\text { progress }\end{array}$ & $\begin{array}{l}\text { Official guide- } \\
\text { lines ('06) } \\
\text { Swedish Energy } \\
\text { Agency }\end{array}$ & $\begin{array}{l}\text { National Stand- } \\
\text { ard ('14) }\end{array}$ & $\begin{array}{l}\text { Official Guide- } \\
\text { line, Motiva } \\
\text { ('12) }\end{array}$ & \\
\hline
\end{tabular}


Table 4: Governmental strategies to boost the EPC market

\begin{tabular}{|c|c|c|c|c|c|}
\hline & Denmark & Sweden & Norway & Finland & Iceland \\
\hline $\begin{array}{l}\text { Legal EE } \\
\text { framework }\end{array}$ & Yes & Yes & $\begin{array}{l}\text { No (Municipal } \\
\text { climate plans) }\end{array}$ & Yes & \\
\hline $\begin{array}{l}\text { Legal EPC specific } \\
\text { framework }\end{array}$ & No & No & No & No & \\
\hline $\begin{array}{l}\text { Official networks } \\
\text { or associations }\end{array}$ & $\begin{array}{l}\text { Yes (ESCO } \\
\text { network) }\end{array}$ & No & No & No & \\
\hline $\begin{array}{l}\text { Research } \\
\text { programs }\end{array}$ & Yes & & Yes & & \\
\hline
\end{tabular}

Table 5: Financial instruments to support EPC

\begin{tabular}{llllll} 
& Denmark & Sweden & Norway & Finland & Iceland \\
$\begin{array}{l}\text { Support scheme } \\
\text { or EE grants } \\
\text { in place }\end{array}$ & Yes & No & Yes & Yes & In progress \\
$\begin{array}{l}\text { EPC specific } \\
\text { grant scheme } \\
\text { in place }\end{array}$ & No & No & No & No \\
\hline
\end{tabular}

Table 6: Barriers and drivers for increased use of EPC

\begin{tabular}{|c|c|c|c|c|c|}
\hline & Denmark & Sweden & Norway & Finland & Iceland \\
\hline \multicolumn{6}{|l|}{ Main drivers } \\
\hline & Success stories & Success stories & Success stories & $\begin{array}{l}\text { High saving } \\
\text { potential } \\
\text { established }\end{array}$ & $\begin{array}{l}\text { Saving potential } \\
\text { on lighting } \\
\text { (LED) }\end{array}$ \\
\hline & $\begin{array}{l}\text { Strong gov. EE } \\
\text { framework }\end{array}$ & $\begin{array}{l}\text { Good coopera- } \\
\text { tion betw } \\
\text { ESCOs and } \\
\text { clients }\end{array}$ & $\begin{array}{l}\text { Gov. EE } \\
\text { framework }\end{array}$ & $\begin{array}{l}\text { Gov. EE } \\
\text { framework }\end{array}$ & $\begin{array}{l}\text { New dev. gov. } \\
\text { subsidies of } \\
\text { electric heating } \\
\text { in households }\end{array}$ \\
\hline & $\begin{array}{l}\text { Economic gov. } \\
\text { support }\end{array}$ & $\begin{array}{l}\text { High saving } \\
\text { potential estab- } \\
\text { lished }\end{array}$ & $\begin{array}{l}\text { Economic gov. } \\
\text { support }\end{array}$ & $\begin{array}{l}\text { Economic gov. } \\
\text { support }\end{array}$ & \\
\hline & Upcoming EPC & & Experienced & & \\
\hline & Standard & & EPC facilitator & & \\
\hline
\end{tabular}




\begin{tabular}{|c|c|c|c|c|c|}
\hline & Denmark & Sweden & Norway & Finland & Iceland \\
\hline \multicolumn{6}{|l|}{ Main barriers } \\
\hline & $\begin{array}{l}\text { Uncertainty } \\
\text { about long } \\
\text { term financing }\end{array}$ & $\begin{array}{l}\text { Complexity of } \\
\text { Public Pro- } \\
\text { curement Act }\end{array}$ & $\begin{array}{l}\text { Lack of trust/ } \\
\text { knowledge } \\
\text { (in parts of } \\
\text { Norway) }\end{array}$ & $\begin{array}{l}\text { Lack of } \\
\text { knowledge }\end{array}$ & $\begin{array}{l}\text { Low priced } \\
\text { geothermal } \\
\text { energy for } \\
\text { heating }\end{array}$ \\
\hline & $\begin{array}{l}\text { Lack of trust/ } \\
\text { knowledge } \\
\text { among some } \\
\text { potential clients }\end{array}$ & $\begin{array}{l}\text { Lack of eco- } \\
\text { nomic gov. } \\
\text { support }\end{array}$ & $\begin{array}{l}\text { Lack of } \\
\text { available/ } \\
\text { experienced } \\
\text { ESCOs }\end{array}$ & Lack of trust & $\begin{array}{l}\text { Low prices on } \\
\text { electricity from } \\
\text { hydro power }\end{array}$ \\
\hline & $\begin{array}{l}\text { Limited specific } \\
\text { EPC support } \\
\text { from the na- } \\
\text { tional admin- } \\
\text { istration }\end{array}$ & $\begin{array}{l}\text { Low energy } \\
\text { prices }\end{array}$ & $\begin{array}{l}\text { Lack of } \\
\text { facilitators }\end{array}$ & $\begin{array}{l}\text { Lack of BP } \\
\text { Examples/ } \\
\text { Success stories }\end{array}$ & $\begin{array}{l}\text { Low cost } \\
\text { savings on } \mathrm{EE} \\
\text { measures }\end{array}$ \\
\hline & & Lack of trust & & $\begin{array}{l}\text { Lack of facilita- } \\
\text { tors }\end{array}$ & $\begin{array}{l}\text { Already use } \\
\text { green energy }\end{array}$ \\
\hline
\end{tabular}

Table 7: Experiences with the EPC model

\begin{tabular}{|c|c|c|c|c|c|}
\hline & Denmark & Sweden & Norway & Finland & Iceland \\
\hline Generally & Mostly Good & $\begin{array}{l}\text { Good, } \\
\text { a few bad } \\
\text { experiences }\end{array}$ & Mostly good & $\begin{array}{l}\text { Many small } \\
\text { projects, few } \\
\text { BP examples }\end{array}$ & \\
\hline $\begin{array}{l}\text { Best Practice } \\
\text { Examples } \\
\text { available }\end{array}$ & Yes & Some & Yes & Few & \\
\hline
\end{tabular}

Table 8: Central Contacts in each country

\begin{tabular}{llllll} 
& Denmark & Sweden & Norway & Finland & Iceland \\
$\begin{array}{l}\text { Authorities and } \\
\text { EPC experts }\end{array}$ & $\begin{array}{l}\text { Easily } \\
\text { accessible }\end{array}$ & Available & $\begin{array}{l}\text { Easily } \\
\text { accessible }\end{array}$ & Available & $\begin{array}{l}\text { Easily } \\
\text { accessible }\end{array}$ \\
$\begin{array}{l}\text { ESCOs/EPC } \\
\text { providers }\end{array}$ & Available & Available & Available & $\begin{array}{l}\text { Mostly } \\
\text { available }\end{array}$ & \\
EPC Facilitators & Yes & Yes, partially & Yes & No & \\
\hline
\end{tabular}




\subsection{Preliminary recommendations}

Based on the information gathered some preliminary findings and recommendations for the further development and promotion of EPC in the Nordic Countries is presented below.

\subsubsection{Governmental strategies for information and training}

Governmental strategies for promotion and training of the various stakeholders in EPC projects have been an important driver. In Sweden and Finland these schemes have been on and off and we would recommend a continuous effort from the authorities to lessen the barriers of knowledge and trust and hence boost market growth.

\subsubsection{Governmental financial support schemes}

Financial incentives for energy savings in general and EPC in particular seem to have made a positive difference to strengthen the EPC market in Denmark and Norway. Both grants for measures (Norway/Finland) and green interest rates (Denmark/Norway) have undoubtedly been strong drivers, making the decision to go forward with the EPC process much easier for the public clients. The unstable financial incentives in Sweden is part of the reason for variations in the market, supporting the thesis that grant schemes do influence the EPC market even though the projects are "self-financing" because savings cover the costs.

The psychology of the governmental support for EE measures which can be used for EPC, in addition to making the projects even more profitable, seems to be that clients perceive these grants as a quality stamp of the EPC concept itself. Hence, they help remove the uncertainties due to the complexity of the model.

\subsubsection{National Standards for EPC}

The complexity of the existing procurement laws is undoubtedly a barrier in all countries and even more when no official standard for EPC is present. This represents national barriers for EPC, but also for ESCOs being able to offer services across borders.

The existence of an official standard for EPC has made a difference in Norway and the upcoming standard in Denmark has also been a strong driver. The obvious advantages of having the various elements 
in an EPC project explained and regulated aside, it also serves as a quality stamp and simplifies the process for all parties. We would therefor strongly recommend the development of national official standards in all the Nordic countries, and hopefully Sweden and Finland could benefit from the work already done in Norway and Denmark. One should consider what could be done to speed up the process to make standards applicable in each country.

\subsubsection{EPC website}

To promote the EPC concept, EPC providers and facilitators we recommend the development of an EPC website in order to make it easier for the building owners to get the process started.

Such a website can contain the following:

- Nordic administration of information and registers.

- Statistics, Guidelines, Standards.

- European Code of Conduct (description below).

- Best Practise database.

- Registers of EPC projects.

- List of and links to EPC providers and facilitators.

The ultimate solution would be to establish a Nordic website on EPC. This could gather all the necessary information and link to national sites and information when necessary.

The web site(s) should be promoted actively by all involved actors (EPC providers, energy authorities etc.).

\subsubsection{European Code of Conduct for EPC}

The European Code of Conduct ( $\mathrm{CoC}$ ) for EPC is a set of values and principles that are considered fundamental for the successful, professional and transparent implementation of EPC projects in European countries. The code was launched by the Transparense project in 2014 in cooperation with the European ESCO associations of EPC providers and the European Federation of Intelligent Energy Efficiency Services (EFIEES). The CoC currently has more than 160 signatories across Europe, including 12 national associations of EPC providers. 
The $\mathrm{CoC}$ has been disseminated and is administrated in Denmark, Sweden and Norway. Almost all active ESCOs in these three countries have become signatories. Information about the $\mathrm{CoC}$ and the advantages of getting signatories are recently sent to Motiva in Finland. The code can be one of many connecting links between the Nordic countries.

\subsubsection{Increased number of EPC facilitators}

In Denmark and Norway experienced and active facilitators have made a positive difference promoting the EPC concept and initiating EPC projects. In all the Nordic countries there are only a few active facilitators, and the role they undertake are different. Actions should be taken to increase the number of facilitators, strengthen their role and hence increase the number of successful EPC projects.

This would lead to a more ESCO-neutral process and lead to the use of official standards or more uniform model documents. This would also save time and resources for all parties and the whole process would be more foreseeable. A facilitator taking the role as mediator might help the barriers of asymmetries of knowledge between clients and providers. A successful facilitator will aim to make the EPC projects profitable for both clients and providers as bad projects will harm the general market and the facilitators' reputation in the long run.

\subsubsection{One Nordic EPC market}

The ultimate goal would in our opinion be a common Nordic EPC market. Several of the above mentioned new actions would be a natural part in a common market. The already tested actions proven most effective in the different countries should be considered implemented in the others. This will be a long process that must be taken in steps, with the simplest actions done first and the more complex changes being a result of the market development.

Below we suggest a preliminary list of steps:

- Step one: (0-1 years):

- Common webpage for EPC in the Nordic countries.

- Training of EPC facilitators as both experts and mediators.

- Governmental information schemes. 
- Step 2: (1-2 years):

- Official national standards for EPC (presently in NO/DN).

- Funding schemes and green interest rates for EPC (presently in NO/DN).

- Nordic ESCO association (presently in DN/S).

- Step 3: (2-5 years):

- Governmental grants for non-profitable EE measures (presently in NO/FI)Procurement laws simplified and applicable to make it possible for ESCOs to offer services across the Nordic boardersInitiate new Nordic accounting rules for credit ratings. 



\title{
Sammendrag
}

\author{
EPC i de Nordiske landene
}

Målet med rapporten er å beskrive Energy Performance Contracting (EPC) markedene i de nordiske landene, deres spesielle egenskaper, trekk og forskjeller så vel som suksess faktorer og barrierer. Rapporten kommer med anbefalinger for tiltak og prosjekter for videre utvikling av EPC markedet i Danmark, Sverige, Norge, Finland og Island med fokus på mulig samarbeid for å fremme EPC i og mellom de nordiske landene.

For alle landene, unntatt Island, har det vært en rekke EPC prosjekter både i offentlig og privat sektor. Rapporten fokuserer på offentlig sektor av to grunner. For det første ser denne sektoren ut til å være mer lovende med tanke på antall prosjekter, sparepotensiale, etterspørsel og prosjektenes størrelse. For det andre er EPC prosjekter i offentlig sektor lettere å kartlegge da utviklingen har blitt fulgt tett av nasjonale energimyndigheter gjennom flere år.

\section{Markedsstatus}

I Danmark og Norge er EPC markedet sterkt og videre vekst er forventet forutsatt at de rammebetingelsene som har skapt denne veksten videreføres. De første årene av 2000-tallet var Sverige ett av de lendende landene innenfor EPC og ble sett på som en pioner og et godt eksempel, ikke bare for Norden, men i Europa. Gjennom de siste årene har imidlertid det svenske EPC-markedet blitt vesentlig svekket og det finnes barrierer rundt kunnskap, tillit og usikkerhet rundt offentlige innkjøpsregler. I Finland er markedet tregt og foreløpig ganske lite, men den siste tiden har offentlig sektor vist mer interesse. Både i Sverige og Finland har det nylig vært en positiv utvikling i markedet ved at noen nye og gode prosjekter har blitt satt i gang. Dette vil kunne tjene som gode eksempler og et lenge etterlengtet dytt i riktig retning. 


\section{Sammenlikninger og anbefalinger}

En god forretningskultur er avgjørende fordi kompleksiteten i EPC prosjektene krever gjensidig tillitt til både teknisk kompetanse og etisk oppførsel. Alle de fire landene har allerede en god og veletablert forretningskultur som en positiv ramme og suksessfaktor for EPC.

Oppstart og utvikling av EPC markedet har fulgt ulike løp i de nordiske landene. I Danmark har kommunene selv vært den viktigste drivkraften, mens det i Norge har vært en fasilitator som har hatt spilt en aktiv rolle. I Sverige har EPC tilbydere (ESCOs) være de mest distinkte pådriverne og i Finland har energimyndighetene ledet an i viktige markedsføringsaktiviteter.

I alle fire landene har finansielle støtteprogrammer, gode eksempelprosjekter og dokumenterte resultater vært avgjørende for fremgang i den grad de har eksistert. På den andre siden har manglende kunnskap, få eller lite aktive fasilitatorer og kompleksiteten i EPC konseptet og innkjøpslovgivingen vært en brems for fremgang.

Rapporten har, basert på sammenlikning av hva som har påvirket markedet enten positivt eller negativt kommet med en rekke anbefalinger for promotering og videre utvikling av EPC i hvert enkelt land. En generell anbefaling er å ta suksessfaktorene fra hvert enkelt land, tilpasse og innføre dem i de øvrige landene. Punktene under er de viktigste suksessfaktorene for EPC i de Nordiske landene:

- Offentlig promotering i form av informasjon og opplæring av relevante aktører.

- Offentlige finansielle støtteordninger.

- Utvikling av offisiell standard for EPC.

- Egen EPC side på internett.

- $\varnothing \mathrm{kt}$ antall aktive EPC fasilitatorer.

En generell anbefaling er derfor at disse tiltakene videreføres eller innføres for å fremme vekst og stabilitet i EPC markedet. Rapporten gir også anbefalinger for mulige samarbeidsprosjekter og en mulig fremdriftsplan for et felles nordisk EPC marked skisseres. 


\section{References}

\section{Denmark}

Transparense report "D2.4 Country report on identified barriers and success factors for EPC project implementation - Denmark", by EC Network, November 2013.

Transparense report "D2.5 Country Report on Recommendations for Action for Development of EPC Markets - Denmark", by EC Network, June 2015.

Experiences with ESCO contracting in Denmark and abroad, MEMO, for The Danish Energy Agency by Rambøll, June 2014.

Input from Nils Daugaard, EC Network.

Presentations from the Danish energy agency, Energistyrelsen, June 2015.

\section{Sweden}

Transparense report "D2.4 Country report on identified barriers and success factors for EPC project implementation - Sweden”, November 2013.

Transparense report “D2.5 Country Report on Recommendations for Action for Development of EPC Markets - Sweden".

ESCO Market Report 2013, Paolo Bertoldi, the European Joint Research Centre.

EEF website, www.eef.se

Input from Jenny Gode, IVL.

Input from Anders Pousette, Energimyndigheten.

\section{Norway}

Transparense report "D2.4 Country report on identified barriers and success factors for EPC project implementation - Norway", November 2013.

Transparense report “D2.5 Country Report on Recommendations for Action for Development of EPC Markets - Norway", August 2015.

Input from national EPC expert/facilitator Kjell Gurigard.

Kommunenes sentralforbund web site: www.ks.no

Kommunalbanken web site: www.kommunalbanken.no

Presentation by Øyvind Moe, Enova SF, May 2015.

Presentations and updated data form Kommunalbanken Norway, KBN, the national municipal bank lending to the local government sector.

Presentation by Siv. Ing. Kjell Gurigard, May 2015. 


\section{Finland}

Motivas web site: www.motiva.no

Input from Isa-Maria Bergmann, Motiva Oy.

ESCO Market Report 2013, Paolo Bertoldi, the European Joint Research Centre.

\section{Iceland}

ORKUSETUR web site: www.orkusetur.is

Presentation; "Consumer advice on energy" by Helga Barðadóttir, Ministry of Industry, Energy and Tourism.

Input from Sigurður Ingi Friðleifsson, ORKUSETUR. 
Ved Stranden 18

DK-1061 Copenhagen K

www.norden.org

\section{EPC in the Nordic Countries}

Energy Performance Contracting (EPC) is a contract model where an energy service provider - ESCO - map and implement profitable energy efficiency measures in buildings or installations. The ESCO guarantees reduction in energy use, and the reduced costs will finance the investments.

The report describes the EPC markets in the Nordic countries, their characteristics, similarities and differences as well as the success factors and barriers. Many successful EPC projects have been implemented and positive experiences have been made. However, there is a large potential for further development of the EPC model with resulting energy savings and $\mathrm{CO} 2$ reductions in the Nordic countries.

The report aim to provide recommendations for action for the successful development of the EPC market in Denmark, Sweden, Norway, Finland and Iceland and possible cooperation to promote EPC in and between these countries.

TemaNord 2015:579

ISBN 978-92-893-4409-8 (PRINT)

ISBN 978-92-893-4410-4 (PDF)

ISBN 978-92-893-4411-1 (EPUB)

ISSN 0908-6692

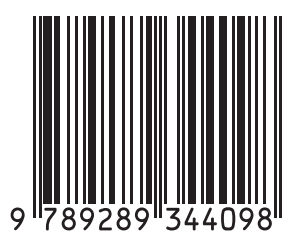

